\title{
VERBOS DE RESPUESTA: ANÁLISIS LÉXICO-CONSTRUCCIONAL
}

\author{
Nicole Delbecouf \\ K.U.Leuven \\ Nicole.Delbecque@arts.kuleuven.ac.be
}

\begin{abstract}
Resumen
The hypothesis is (i) that answering predicates cannot be assimilated to communication predicates, and (ii) that responder and contestar do not have the same meaning. Even where there seems to be some overlap, (i) answcring predicates have a proper conceptual structure, and (ii) the individual verbs instantiate a differcnt framing. The meaning structure of the verbs emerges through generalization and spccification processes and various mechanisms of metaphorical and metonymical extension. The network metaphor captures the dynamic nature of the semantic categories as well as the relations between them. The variety of constructions brings to the fore the relational dimensions that can be alternately profiled. In order to deal with questions left unaccounted for by exclusively Iexicalist or constructionist approaches, the focus is on semantic role fluctuations and on the interaction between constructional meaning and lexical semantics.
\end{abstract}

\section{DOS VERBOS: DOS CONCEPCIONES, DOS REDES SEMÁNTICAS}

El análisis de los predicados de respuesta es un reto tanto del punto de vista léxico como del punto de vista sintáctico. La variación y alternancia que se observa más especialmente en el uso del dúo formado en español por los verbos contestar y responder plantea cuestiones teóricas y descriptivas particularmente intrincadas. Convendría analizar también verbos menos frecuentes, como rebatir, refutar, replicar, reponer, que parecen ocupar un lugar menos central en el campo semántico de la RESPUESTA. Esto será más fácil una vez que hayamos desenredado los significados de responder y contestar. El interrogante es doble. Primero: ¿cómo situarlos frente a otros predicados, en particular - pero no únicamcnte - la categoría de los predicados de comunicación? Y, segundo, ¿cuál es la relación que existe entre los propios verbos responder y contestar?

La acción de contestar/responder tiene una importancia funcional relativamente importante en nuestra cultura: cuando alguien nos dirige la palabra, las más elementales reglas de cortesía requieren una reacción de nuestra parte. Se trata de algo significativo para la interacción social (cf. Goffman 1981). Ejemplos como (1) y (2) sin duda nos suenan a más de un título.

(1) - (...) Mil veces me he hecho la misma pregunta: ¿por qué estamos aqui?

-El mundo es un puente. Pasad por él pero no os instaléis en él.

-Pero -insisti- no has respondido a mi pregunta... 
- Sí, Jasón, sí lo he hecho. Este mundo es como la antesala del Reino de mi Padre. Prepárate en la antesala, a fin de que puedas ser admitido en la sala del banquete. ¡Sé caminante que no se detiene! (J.J. Benítez, 1984)

(2) - Pero, ¿por qué no os queréis casar?, digo yo.

- Mamá, por favor, ¿te quieres meter en tus cosas?

- Primero contéstame.

- No nos queremos casar porque no creemos en el matrimonio. (A. Marsillach, 1995)

Por sencillo y básico que sea el acto de contestar/responder, es evidente que lo percibimos de maneras muy variadas y le atribuimos funciones y efectos distintos en términos de interacción humana. Podemos suponer que esto se reflejará en la variedad de construcciones y participantes que admiten los dos verbos.

Si consideramos que el análisis lingüístico tiene por cometido proveer una aclaración integrada e integradora del conjunto de los fenómenos relacionados con los verbos en cuestión, hay que prestar atención a su relevancia funcional-cognitiva a la hora de emprender el análisis semasiológico, e intentar captar las relaciones que puedan existir entre distintos sentidos, por un lado, y distintas construcciones, por otro. Significa que no es suficiente decir que contestar sólo denota una realización, mientras que responder también puede denotar un estado, sino que hay que estar dispuestos a acoger cuán vaguedad y polisemia sea posible acomodar sin desechar extensiones metafóricas ni interpretaciones figuradas en general.

La hipótesis de este estudio es que responder y contestar no significan lo mismo y que incluso donde parecen traslaparse sus significados, remiten a un esquema conceptual diferente. Anticipando sobre los resultados del análisis, y simplificando a ultranza, la imagen que evocan puede representarse como en las figuras 1 y 2.

1

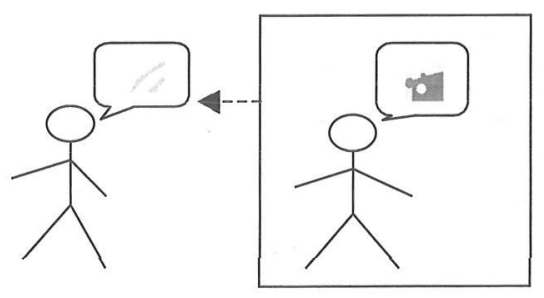

Figura 1. La imagen evocada mediante el predicado «contestar».

En la imagen evocada por contestar destaca la asociación entre dos actos de habla vista desde la perspectiva del segundo locutor, que desempeña el papel reactivo.

La imagen de responder también es dual, pero es más abstracta. El perfil de las entidades conectadas no es necesariamente personalizado. Pueden ser de índole variada: unidad semiótica, creación artística, proceso natural, etc. 
1.

2.

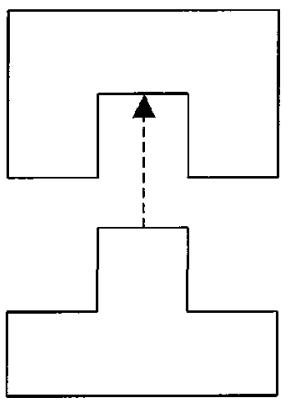

Figura 2. La imagen evocada mediante cl predicado «responder».

La represcntación mental asociada con un vocablo - -aquí el verbo de respuesta-com prende una configuración de parámetros a partir de la cual el vocablo se asocia con la situación representada en el discurso. Los elementos del contexto contribuyen a fijar los valores específicos atribuibles a los parámetros en juego. A continuación procuraré mostrar que la configuración paramétrica, o sea, la representación esquemática de los dos verbos, se inserta en modelos cognitivo-culturales distintos. Significa que aun cuando responder y contestar parecen sustituibles uno a otro, no activan la misma representación mental. Es decir, pueden «referirse» a la misma situación, pero no por esto «denotan»lo mismo, sino que proyectan la instanciación concreta sobre una red semántica diferente que sigue presente como trasfondo.

EI enfoque cognoscitivo procura arrojar luz sobre los modos de conceptualización que encierran las construcciones en que se integran los distintos lexemas. Las propiedades formales del lenguaje se examinan desde su perspectiva conceptual: la aproximación cognoscitiva se propone dar cuenta de la estructura gramatical en términos de las funciones que sirve en la representación de la estructura conceptual. Dos nociones básicas caracterizan al paradigma cognoscitivo: (i) un mismo evento puede ser conceptualizado de distintas maneras; (ii) la pertenencia a una categoría no se define a través de condiciones necesarias y suficientes, sino que el límite entre categorías es difuso y da cabida a miembros periféricos.

De ahí que este enfoque siga una lógica reticular para captar la naturaleza dinámica de las categorías: en una estructura radial se puede pasar de una entidad a otra y varias entidades pueden llegar a fusionar hasta cierto punto. Langacker (1991: 266) analiza los miembros de una categoría como modos en una red, vinculados unos a otros por varios tipos de relaciones categorizadoras». De estas relaciones, la «instanciación» y la «esquematización» son particularmente relevantes, ya que permiten unir bajo una estructura más abstracta y general (el esquema) varias construcciones estructuralmente más variadas (las instanciaciones). La relación entre los distintos nodos (significados) scrá percibida como más o menos estrecha scgún que se encuentre a una distancia más o menos grande del prototipo.

Siguiendo la idea de que no hay incompatibilidad entre una teoría de categorización basada en la distinción prototipo/pcriferia y la aceptación de un nivel de lingua mentalis 
para estructuras semánticas (cf. Wierzbicka 1985)는 utilizaré la representación topológica de inspiración langackcriana para analizar los verbos responder y contestar.

Para hablar del significado en términos de conglomerados conceptuales (clusters), la metáfora de la red permite captar la naturaleza đinámica de las categorías semánticas así como de las conexiones entre ellas. Existen varias mancras para establecer y activar conexiones cntre dos o varios de los nodos que constituyen una red. Así, por ejemplo, de acuerdo con la concepción relativista del universo y sus componentes (apoyada por la física moderna y otras disciplinas) una categoría - nodo - puede difuminarse e integrarse en otra.

En mi análisis de responder y contestar procuraré mostrar que según el nodo por donde se entre en la red, cambia la perspectiva y variará la manera de distinguir cntre significado de base y sentidos derivados. Disponemos, en efecto, de varios procedimientos de ampliación: además de los tradicionales procesos de generalización y especificación, también conviene tomar en cuenta varios mecanismos de extensión metafórica y metonímica. O sea, que sigue de actualidad la idea griega del panta rei. Todo fluyc, y aunque las conclusiones que saque el analista dependerán del punto de vista que elija, esto no le exime de multiplicar las obscrvaciones hasta alcanzar la visión caleidoscópica más completa posible. Así es como acaba por emerger la estructura semántica interna de cada verbo. Las figuras 3 y 4 representan de forma esquemática sus respectivas redes scmánticas con las principales conexiones entre los diferentes nodos. Los grandes espacios rectangulares delimitados por líneas quebradas señalan los dominios generales y las variantes prototípicas vienen enmarcadas y marcadas en negrita.

La red de responder se mucve en cuatro dominios. En torno a la expresión verbal, que puede considerarse el dominio central, se conciben, en paralelo, dos dominios laterales en que la dimensión verbal no es condición necesaria. Y todo lo que son reacciones no verbales constituye un dominio lateral aparte. El gráfico da cabida a las variantes encontradas y muestra las principales interconexiones entre ellas. Las líneas flechadas indican la dirección de la instanciación, partiendo de lo más esquemático y yendo a lo más elaborado. En sentido inverso, las líneas quebradas señalan la dirección de las extensiones. Las descripciones en las casillas no tienen por cometido dar definiciones exhaustivas, sino etiquetar los conceptos más importantes asociados con una variante particular. Pura expresar las relaciones entre esos conceptos, me sirvo de frases para sugerir que tras todas y cada una de las representaciones encasilladas hay un modelo mental complejo del evento evocado por tal o cual subsignificado. Para describir aquellos modelos haría falta introducir gran cantidad de parámetros y valores.

La red de contestar presenta una estructuración más densa que la de responder. A los vínculos trazados en la figura 4 se podrian añadir algunos más para señalar interconexiones suplementarias entre varios de los nodos de la red. Otra vez tenemos un antecedente y un postcedente, pero ahora sin inversión posible de la direccionalidad: el hablante se pliega al marco situacional tal como se le presenta, y si bien puede adaptar hasta cicrto punto el guión, la iniciativa sigue escapándolc. Mucho más que con responder, en cambio, se perfila el tipo de actuación, a menudo en combinación con especificaciones acerca de acciones y actitudes concomitantes con el papel reactivo desempeñado. Al ser sólo parte de la acti-

1 La lingua mentalis para estructuras semánticas es constituida de una serie de primitivos (preconceptuales), tratados como unidades a base de las cuales se componer estructuras más complejas. 


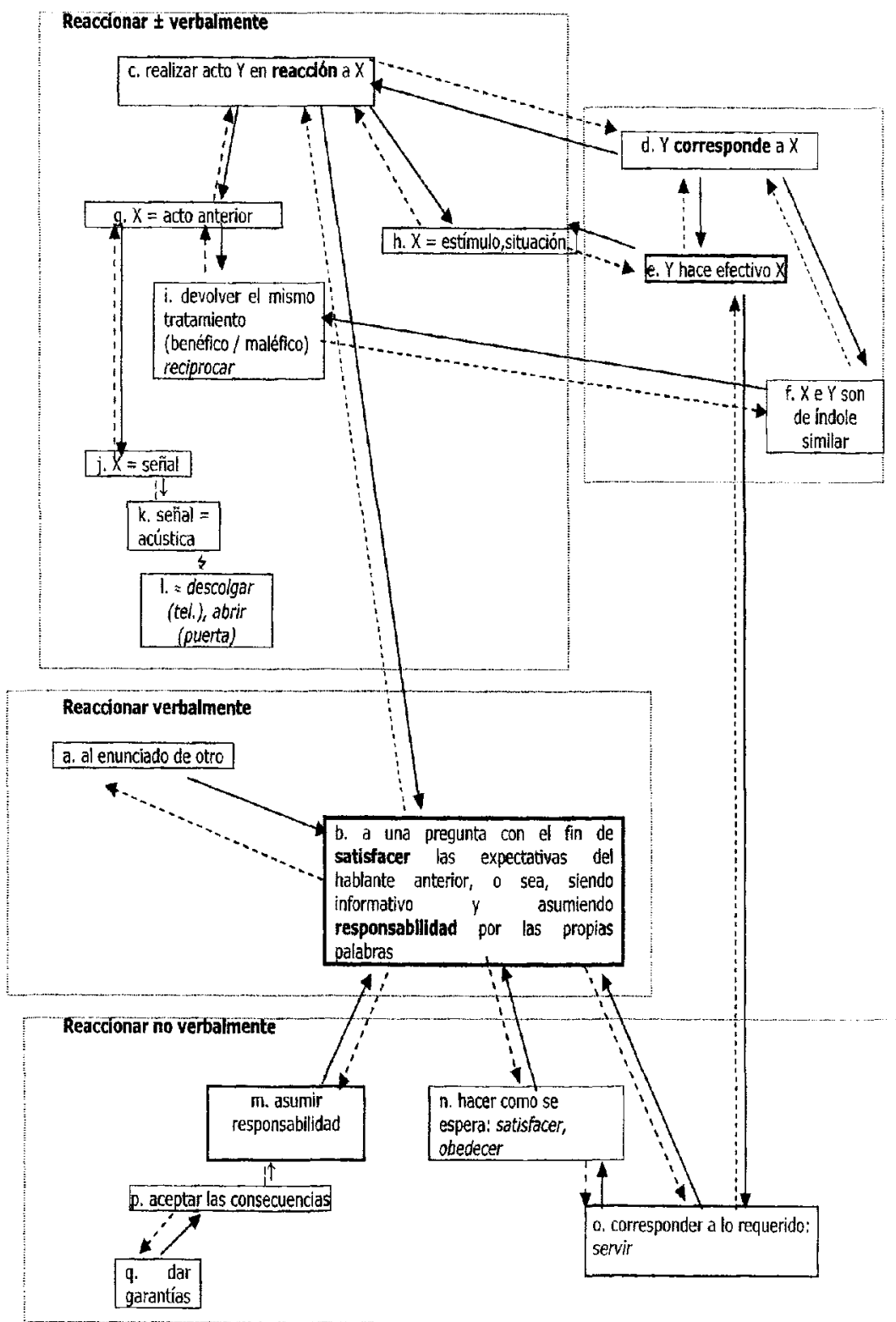

Figura 3. Representación esquemática de la estructura reticular del significado de responder: 
conativo (el contestador automático)

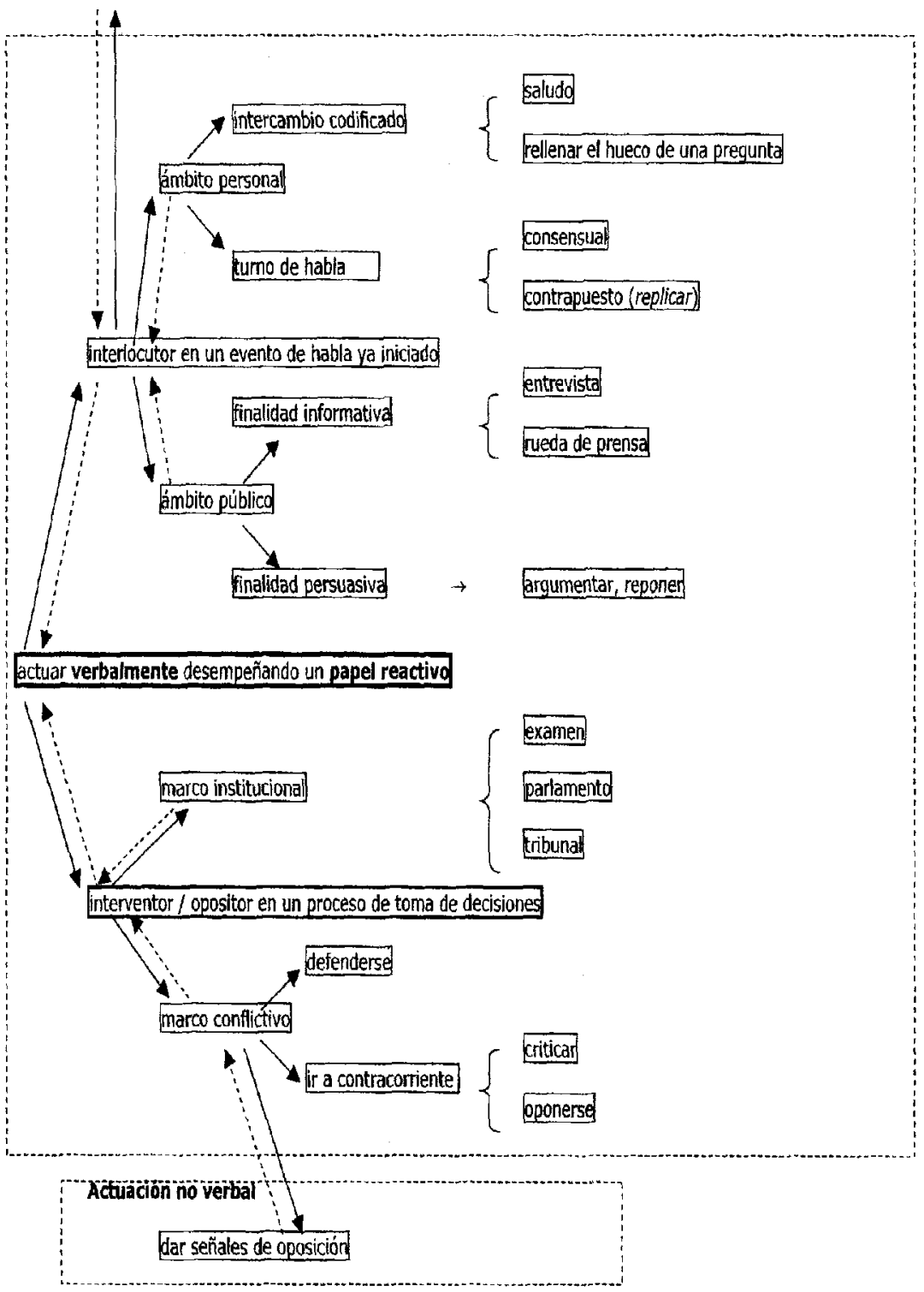

Figura 4. Representación esquemática de la estructura reticular del significado de contestar. 
vidad desarrollada por el agente, el aspccto interactivo - por focalizado que esté - no lo ocupa ni identifica completamente, sino que nos aparece como dirigido por los requisitos del guión, que proviene del evento de habla mayor que da cabida a la contestación. De ahí que haya espacio para varios tipos de actuación --incluida la simulación-y que la manera de contestar resulte reveladora del papel social asumido en un determinado momento: uno contesta de forma distinta scgún que se comporte como amigo, compañero, vecino, o haga de jefe, abogado, ministro, etc. Deriva su protagonismo en la escena del rol que interpreta (cf. Goffman 1959: 251). De ahí que no sea raro que intervengan relaciones de dependencia que dan lugar a cierta asimetría en la relación entre el hablante $\mathrm{Y}$ (el contestador) y $\mathrm{X}$ (el iniciador del intercambio) en función de su respectivo estatus (por ejemplo: médico vs. pacientc, ministro vs. periodista). Mientras que responder hace abstracción de la dimensión del juego social, contestar lo pone en evidencia.

A continuación presento cl recorrido que ha desembocado en el diseño de estas redes semánticas. Después de mencionar la base empírica, procuro situar el campo semántico de la respuesta de manera general, haciendo hincapić en los conceptos subyacentes. Luego paso rcvista a la variedad de construcciones con el fin de destacar cuáles son las dimensiones relacionales que pueden verse alternativamente perfiladas. A cada paso mencionaré las correspondencias formales y funcionales más distintivas, señalando donde cabe los problemas que una aproximación exclusivamente lexicalista o construccionista dejaría sin resolver.

\section{DE LA INFORMaCión LEXICOGRÁFICA AL BANCO DE DATOS CREA}

La lexicografía da por sentada una sinonimia parcial entre responder y contestar. Una rápida consulta de varios diccionarios sugiere que la estructura scmántica de responder es más complcja que la de contestar. Toda una serie de indicios apuntan en esta dirección:

(i) suele haber más menciones de contestar bajo responder quc viceversa;

(ii) se cuentan más subcntradas para responder que para contestar;

(iii) se mencionan más verbos parcial o potencialmente equivalentes o casi sinónimos con responder;

(iv) se ejemplifica un mayor número de construcciones diferentes con responder que con contestar;

(v) en las definiciones de responder se entremezclan más criterios construccionales;

(vi) hay menos convergencia conceptual y explicativa entre los diccionarios para responder;

(vii) el número de derivaciones, la «familia» derivacional de responder es bastante mayor.

De las definiciones lexicográficas, ilustradas en su mayor parte por las mismas construcciones, sc desprende que en cuanto a los tipos de evento expresables por uno y otro, suele tratarse - en terminología vendleriana - de eventos dinámicos y télicos, o sea, de realizaciones o logros, según que sean o no interpretados como durativos. Se señala, además, que responder puede denotar un estado y una disposición.

La información contenida en los diccionarios no permite, sin embargo, profundizar el tema en el sentido deseado. Para llevar a cabo la investigación es imprescindible tener acceso al uso real en sus más variadas manifestaciones y proceder de manera inductiva. Esto 
sólo es posible al disponer de un gran corpus fácilmente consultable. El Corpus de Referencia del Español Actual de la Real Academia (CREA) cumple todas estas condiciones. Para mantener la suficiente homogeneidad, me he limitado al subconjunto de los datos de España ${ }^{2}$. Como se ve en el cuadro 1, es un muestrario suficientemente amplio para que tenga validez como base empírica.

\begin{tabular}{|l|l|l|l|l|}
\hline \multirow{2}{*}{ Verbos } & \multicolumn{2}{|c|}{ CREA: } & \multicolumn{2}{|c|}{ CREA: } \\
\cline { 2 - 5 } & Ocurrencias & Documentos & Ocurrencias & Documentos \\
\hline Responder & 24541 & 9450 & $1259451,3 \%$ & 5296 \\
\hline Contestar & 13789 & 4428 & $790957,3 \%$ & 2867 \\
\hline
\end{tabular}

Cuadro 1. Frecuencia absoluta y relativa de responder y contestar en CREA-España con respecto al total.

\section{CONCEPTIOS SUBYACENTES AL CAMPO SEMÁNTICO DE LA RESPIJESTA}

Para situar el campo semántico de la RESPUESTA yendo de lo más general a lo más particular, se pueden distinguir esencialmente cuatro dominios que inciden directamente en la noción de RESPUESTA como concepto constitutivo de un campo semántico: (i) la base espacio-temporal, (ii) el dominio de la comunicación, (iii) el de control, (iv) el de la dinámica de fuerzas.

\subsection{La base espacio-temporal}

En la base espacio-temporal se incluyen los hechos relativos a los dominios físicos de las entidades participantes así como las relaciones espaciales entre ellas que pueden cambiar sobre el vector temporal. El marco esbozado en la figura 5 constituye la base para los predicados responder/contestar: en la medida que designan la emisión y transmisión de un enunciado del locutor (L) al interlocutor (I) envuelven necesariamente una dimensión temporal. La imagen que tenemos del evento se refleja en la expresión «dar una respuesta/ contestación» (3-4).

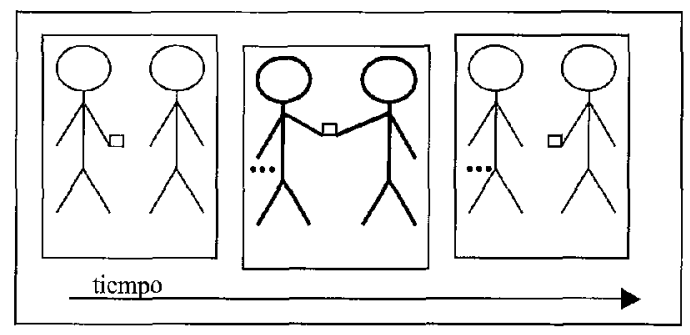

Figura 5. La base espacio-temporal de «dar algo a alguicn».

2 Sin análisis pormenorizado de la aportación de los diversos subgéncros, no resulta posible interpretar la proporción ligeramente más alta de contestar en España que $\mathrm{cn} \mathrm{cl}$ resto de los países hispanohablantes. 
(3) a. (..) alguien lc había preguntado: «Por qué vas a un psicoanalista». No dio la respuesta estilo Woody Allon. Dio una respuesta mucho más inleresante y dice: «Cada uno tiene un secreto en su vida. Un secreto para sí mismo. Hay quien se lo lleva a la tumba y hay quien decide saber algo de él, ponerse a descifrar ese secretoy. (24/04/97, Cadena SER)

b. No son curiosidades, perdón, son preguntas muy concretas, y que usted, y cualquier persona y más preguntas que nos que nos podamos plantear, ¿no? Mire, yo le podría dar respuesta en estos momentos a esas dos preguntas, pero, insisto, prefiero no vamos a vamos a dejar que la investigación discurra. (13/03/97, Cadena SER)

c. También pensamos que es la primera vez que se da una respuesta tan rotunda a ETA, y al misno tiempo a su cómplice, que scrá HB (11/06/88, TVE 1)

(4) a. Les dimos tambićn cl tcléfono de nuestro contestador automático, al que podían llamar para darnos su contestación y el teléfono es el Nueve-cero-cero-uno-cero-unocuatro-dos-ocho. Apúntelo bien porque es el mismo teléfono al que pueden llamar para contestar a la pregunta que les haremos en ¿Usted qué haría?, nueve-nueve-unocero-uno-cuatro-dos-ocho. ¿usted qué haría?, ¿se le ocurre algo?, dígalo muy pronto, digalo ya. (Madrid, 26/02/9I, Radio 5)

b. Para dar contestación a estas preguntas, el arzobispo de Valladolid cita diversos pasajes de la Sagrada Escritura que se refieren a los sufrimientos que padeció Cristo por amor a los hombres. (ABC, 09/04/1985)

c. Según la misma encuesta del CIS, entrc los más partidarios de la concertación están los votantes del PSOE y dcl Partido Popular, que, respectivamente, dan una contestación afirmativa un 57,3 y un 60,6 por 100 de los preguntados. ( $\mathrm{ABC}, 01 / 05 / 1989$ )

Ahora bien, contrariamente a lo que sugiere el modelo con dar, los verbos responder y contestar no se entienden en términos de TRANSFERENCIA más que por proyección metafórica a un dominio más específico, a saber el de Comunicación. Este marco analógico lleva a ampliar el concepto de «objeto transferido» para dar cabida a objetios semióticos: en vez de ser material, el objeto que se transfiere es una secuencia de signos cargada de significado. Su contenido proposicional suele expresarse en discurso directo (5) o indirecto (6), al que se remite a veces anafórica o catafóricamente por una forma (pro)nominal neutra (7) 0 un pronombre interrogativo (8). Nótese que la interrogación indirecta parecc scr cxclusiva de contestar (6b), que asimismo admite formas mezcladas de discurso directo e indirecto (6c); parece, pues, más propicio que responder para remitir a la escenificación de situaciones dialogales (cf. Delbecque 2000).

(5) a. Me prcgunta cuánto tiempo he pasado en la India. "Tres meses», respondo. (M. Leguineche, 1995)

b. Le contesté a $\Lambda$ ugusto con bastante rapidez y en voz alta:

.- Bien... No pasa nada... ¿Queréis que me vaya? (J.R. de la Morena, 1995)

(6) a. Le respondi que la familia, inchido yo, naturalmente, no hablábamos con Franco de esos asuntos. (L. Herrero, 1995)

b. Vamos a hablar de esos reportajes, de todas maneras no me ha contestado usted por qué no hace cine. (TVE $1,20 / 09 / 90$ )

c. Yo te contesto que de acuerdo y listo. (J. Cacho Cortés, 1988)

(7) a. En una encuesta efectuada en 1973 por Diez Nicolás en mujeres en edades comprendidas entre los 15 y los 45 años, a la pregunta sobre las cualidades que más admiraban en un hombre, respondieron to siguiente: irabajador (54\%), bueno, formal (37\%), honcsto, honrado (30\%), (...) (E. González. Duro, 1989) 
b. - ¿Picnsa seguir en el INI hasta el 93 ? - Siempre contesto lo mismo. El dia que me contrataron hice dos cosas: (...) (Cambio 16, $\mathrm{n}^{\circ}$ 957, 26/03/1990)

(8) a. - ¿Qué le respondicron? (Cambio 16, $\mathrm{n}^{0}$ 969, 18/06/1990)

b. - ¿Y qué te ha contestado? (F. Fcrnán-Gómez, 1985)

Está claro que tanto el formato de la respuesta como la distancia espacio-temporal entre emisor y receptor, y quizá otros factores del contexto, presentan cicrta variabilidad. A la hora de establecer la red semántica de los predicados contestar y responder, hay que decidir cuál es la extensión que conviene atribuir a estas dimensiones generales de la estructura esquemática. Al incorporar, por ejemplo, la dimensión abstracta del tiempo, no queda claro si también se «transporta» - para asi đecirlo- del dominio fuente al dominio meta, o si simplemente es consistente con alguna estructura esquemática preexistente. Tiendo a optar por la segunda alternativa, por lo cual desisto de hacer mención explícita de la base espaciotemporal en los esquemas individuales de los dos verbos. Esto no significa que el análisis deba quedar confinado al nivel de la estructura argumental. ${ }^{3}$ Como se sabe, ésta se suele caracterizar de manera atemporal por el tipo lógico del predicado verbal, indicando por qué complementos sintácticos debe ser saturado para convertirse en un predicado de eventos. Se dará pues por supuesto que las relaciones entre los participantes se realizan en una estructura eventiva, o sea temporal, que incluyc la referencia establecida a través de la construcción en su conjunto y se presta, por ende, a una diferenciación más matizada.

\subsection{El dominio de la comunicación}

La noción de RESPUESTA se relaciona espontáneamente con el campo de la COMUNICACIÓN, a sl vez un subcampo que corresponde al modelo general de la noción de TRANSFERENCIA (9). La metáfora subyacente al campo de la COMUNICACIÓN ha sido adecuadamente definida por Reddy (1979) y Lakoff (1987: 450-451) en términos de conDucto: en cuanto emisor, el locutor L se concibe como «el que da algo» y el mensaje se percibe como «el objeto dado»), que pasa por el dominio espacio-temporal del locutor $L$ al interlocutor $I$, que es el «receptor». En la figura 6 aparece la diferenciación —en terminología langackeriana «trajector $\rangle-\langle l a n d m a r k »-$, entre el trayector primario, por un lado, y por otro, el «landmark», o sea, la pauta primaria - que es al mismo ticmpo el trayector secundario- $y$, finalmente, la pauta secundaria. (Véase Langacker 1987: 122-122, 217-222.)

3 Las explicaciones lexicalistas se basan en la estructura argumental que se atribuye a cada verbo en el lexicón; la apreciación de las propiedades sintácticas y semánticas se deriva de las propiedades de los elementos léxicos combinados. 


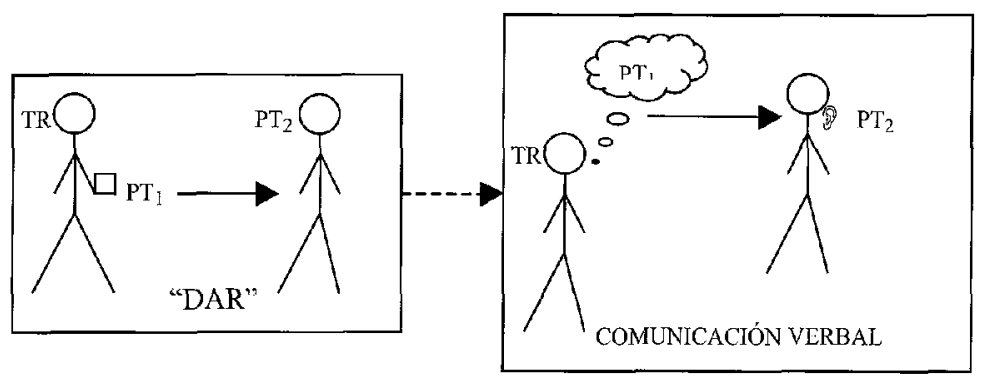

Figura 6. Extensión de «DAR» a la comunicación verbal.

(9) TRANSFERENCIA > COMUNICACIÓN > respuesta

La inclusión de un campo scmántico más específico en otro más amplio, y así sucesivamente - a la manera de las muñecas rusas - es práctica clásica. Sigue la lógica de las categorías conccbidas metafóricamente como «contenedores». Los campos semánticos pueden concebirse como conjuntos que «contienen» lexcmas semánticamente relacionados cuyo parecido semántico puede rastrearse por el hecho de que comparten las mismas posibilidades construccionales. Para el concepto de transferencia y los subcampos que de él se derivan, es bien sabido que la construcción bitransitiva, que da una realización icónica completa del concepto, se suele considerar como la prototipica: el sujeto humano $\left(\mathrm{N}_{0}\right)$ denota la fuente, el régimen directo $\left(\mathrm{N}_{1}\right)$ el objeto, y cl régimen indirecto $\left(\mathrm{N}_{2}\right)$ la meta (10). Al predicado genérico prototípico «dar algo a alguien» le corresponde «decir algo a alguien" para el campo de la COMUNiCACIÓN (cf. Delbecque \& Lamiroy: 1996: 99 ss.). En las construcciones que siguen este modelo, contestar y responder se comportan pues como dar y decir (10-11).

(10) $\mathrm{N}_{0}$ [humano] $+\mathrm{V}_{\mathrm{dar}}+\mathrm{N}_{1}$ [no animado] $+a+\mathrm{N}_{2}$ [humano]

(11) (...) ahora puedo resumir con palabras mías lo que entonces me respondió: obedecía a su necesidad ineludible de justificación. (G. Torrente Ballester, 1988) $\rightarrow(. .$.$) lo que me \{$ dio (como respuesta) / dijo\}

(12) Vecino: - Fs lo que yo le he contestado a mi scñora. (J. Salom, 1980) $\rightarrow$ Es lo que yo le he $\{$ dado como respuesta / dicho\} a mi scñora.

Una vía posible para delimitar el subconjunto que nos interesa consiste en añadir restricciones semánticas sobre los papeles semánticos desempeñados por los tres actantes. La descomposición de la noción de transferencia en movimiento intencional de un objeto hacia una meta se presta a caracterizaciones del tipo de las moncionadas en (13). Las precisiones añadidas a la derecha permiten delimitar el campo de la COMUNICACín, pero aún no logran distinguir los predicados contestar y responder de otros como comunicar, decir, declarar, etc. 
(13) $\mathrm{N}_{0}$ : [Fuente $>$ Agente $>$ Emisor $>$ Locutor $]$

V: contestar, responder, ... decir, comunicar, decir, declarar ... comentar, contar, sugerir, ...

$\mathrm{N}_{1}:$ [Objeto $>$ Paciente $>$ Objeto semiótico $>$ Contenido Proposicional $]$

$\mathrm{N}_{2}:[$ Meta $>$ Destinatario $>$ Receptor $>$ Interlocutor $]$

\subsection{El dominio de control}

Como el objetivo es que la descripción sea distintiva, conviene que nos centremos en los dominios más específicos - a saber, CONTROL y DINÁMTCA DE FUERZAS - que pueden generar diferencias pertinentes en el subcampo de la RESPUESTA.

Las especificaciones del Agente como Locutor, del Paciente como Objeto scmiótico, y del Receptor como Interlocutor pasan por alto una diferencia no desechable entre el macrocampo de TRANSFERENCIA y el campo de la COMUNICACIÓN. En efecto, cuando alguien «da» algo a alguien, en el sentido literal, el conTroc sobre el objeto pasa del agente al destinatario y acaba encontrándose totalmente en manos de este último, fuera del alcance del donante. Sin embargo, no ocurre así en la comunicación. Resulta ser relativo e imperfecto el paralelismo anteriormente invocado según el cual el locutor $L$ controla su respuesta $\lambda$ y el interlocutor I recibe acceso a $\lambda$ como lo recibe el receptor de un acto de transferencia material. Antes de abordar lo que pasa del lado del locutor-emisor (L) y de examinar la modulación del papel del interlocutor-receptor (I), es importante advertir que a menudo ni contestar ni responder llevan objeto dirccto expreso (14-15).

Obsérvese la perspectiva generalizadora y abierta de responder (siempre (14a), si... (14b)), frente al marco específico y altamente codificado en que se inserta contestar (la liturgia en (15a), la relación padre-hijo (15b)). Volveremos a estas diferencias, pero detengámonos primero en el macro nivel.

(14) a. Siempre me ha respondido usted huyćndome y riendo. (ABC Cultural, 20/09/1996)

b. Pero si algo más quieres saber, pregunta, que yo te respondo. (F. Nieva, 1978)

(15) a. -Padre nuestro que estás en los cielos..

Mosén Alberto rezó. Y le conlestaron todos los presentes. (J.M. Gironella, 1986)

b. Mary: Nosotras hemos fracasado. Ni las lágrimas ni las amenazas han servido. A su padre ni siquiera le ha contestado. (M.M. Reina, 1990)

Cuando se trata de transferencia material, lo que uno puede «dan» preexiste necesariamente al evento. Suele tratarse de algo que pertenece al propio ámbito del agente, posiblemente es un objeto que ha fabricado ćl mismo, pero no puede estar creándolo en el acto. Esta ya es una primera gran diferencia: en la comunicación, el control no se efectúa sobre un objeto exterior al agente, sino sobre el propio proceso de creación. Cuando el predicado verbal perfila un acto de habla específico, puede construirse sin objeto explícito. Es el caso de responder y contestar: construidos como en (16), se parccen a una construcción intransitiva como la de mentir (17). En la medida, sin embargo, que los predicados de transferencia y la mayoría de los de comunicación no admiten esta construcción preposicional biactancial (como se ve en (18)), resulta difícil derivar ésta de la construcción bitransitiva. Desde el punto de vista lexicalista lo lógico será concluir entonces que los verbos entran en otra clase semántica, llamémosla provisionalmente la de los predicados de comportamiento reactivo. 
Bajo este análisis, el control queda del lado del agente (Juan) y Pedro es el actante afectado, analizable como dativo beneficiario. Ya no "controla» a su vez, sino que recibe acceso a la visión particular de la que el locutor le quiere hacer partícipe; pero de la construcción no se puede inferir si llega a compartir esta visión o no. Si no se quiere seguir esta lógica, queda como alternativa unificadora la posibilidad de considerar que responder y contestar operan a veces como predicados complcjos y llevan objeto incorporado, o sea, que siguen siendo descomponibles como «dar una respuesta/contestación a alguien».

(16) a. Juan \{responde / contesta\} a Pedro.

b. Juan le \{responde / contesta $\}$ a Pedro.

c. Juan le \{responde / contesta\}.

(17) a. Juan miente a Pedro.

b. Juan le miente a Pedro.

c. Juan le miente.

(18) a. *Juan $\{$ le $/ \varnothing\}$ da a Pedro.

b. *Juan $\{$ le $/ \varnothing\}$ dice a Pedro.

Sea como sea, esta variación construccional obliga a revisar el razonamicnto analógico. $\Lambda$ diferencia de los predicados de transferencia, los de respuesta pueden limitarse a perfilar sólo la fuente y la meta del evento. Por otra parte, la diferencia construccional no parece obstaculizar totalmente la proyección metafórica. Sigue siendo posible, en efecto, concebir la transmisión como un proceso que siguc una trayectoria virtual que va desde $L$ por la respuesta $\lambda$ hasta $I$. Esto puede aducirse como argumento a favor de cierto rclajamiento de la estricta condición de invariabilidad, conocida como la «Invariance Hypothesis» avanzada por Lakoff (1990). Según esta hipótesis, la estructura esquemática del campo-fuente queda preservada. Sin embargo, también existen teorías opuestas. En opinión de Turner (1990, 1993), por ejemplo, prevalece la estructura del campo-mcta. Pero una y otra teoría parten del supuesto de que es inequívoca la identificación de los campos fuente y meta. Sin embargo, en el curso del análisis vercmos que, en realidad, esto no resulta siempre tan evidente como quizá se pudiera pensar.

En efecto, la imagen es vacilante aun en otros respectos. Al igual que los predicados de transferencia, pero a diferencia de la mayor partc de los predicados de comunicación, contestar y responder admiten un complemento preposicional no animado. Esto aumenta la vaguedad conceptual y construccional, $\mathrm{e}$ inspira reflexiones como las de $\mathrm{R}$. Trujillo, citada a continuación:

«Le aparece a veces (...) con verdadero sentido referencial de «lugar», sobre todo con verbos intransitivos en los que el término se siente como inTERno [en negrita en el original] al significado. Está claro, por ejemplo, que en respondi a Maria y respondí a la llamada, ambos terminales guardan idéntica relación con el verbo, pese a que prejuicios designativos puedan hacemos pensar lo contrario. Diríamos, incluso, respondi a ella para ambas situaciones, aunque si añadiéramos $l e$, tenderíamos a sentirlo sólo como referente de Maria, en tanto que no lo identificaríanos igualmente con la llamata en le respondi a la llamada.s (Trujillo 1988: 208)

A la posible ausencia de objeto directo, se añade pues la inseguridad acerca del estatuto sintáctico-semántico del oblicuo introducido por la preposición $a$. Con esto nos alejamos 
aun más de la configuración bitransitiva, considcrada como la típica construcción de los verbos de comUNiCACión. El que los papeles semánticos de los participantes parezcan fluctuantes sugiere que los verbos de REsPuesta no son $\longrightarrow$ o sólo parcialmente- equiparables a una subclase de los predicados de COMUNICACIÓn. Esto quizá explique por qué los verbos de RESPUESTA quedan sin mencionar en el inventario de las clases de verbos que Lcvin (1993) ha establecido para el inglés, ni tampoco aparecen entre los verbos citados en la red semántica de construcciones bitransitivas elaborada por Goldberg (1995: 38). Para salir del paso no queda más remedio quc indagar más a fondo las relaciones entre los participantes.

\subsection{El dominio de la dinámica de fuerzas}

Para llegar a entender mejor las dimensiones relacionales susccptibles de variar conviene introducir como cuarto dominio conceptual el de la dinámica de fuerzas. En términos generales, las acciones se dejan concebir en términos de flujo energético como procesos que se extienden de una fuente de energía a un objetivo en que se «deposita» esta energía. ${ }^{4}$

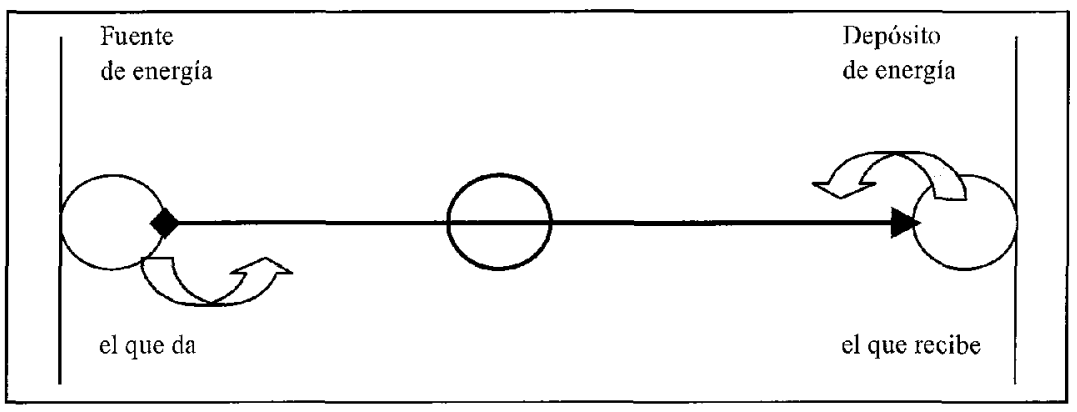

Figura 7. La dinámica de fuerzas (rcprescntación adaptada de Newman 1996: 50)

La figura 7 evoca la imagen del tipo de evento más generalmente asociado con predicados de acción, cntre cllos los de transferencia y hasta cierto punto los de comunicación (si hacemos abstracción de la dimensión de control). Sin embargo, esta representación unidireccional es insuficiente para dar cuenta del perfil relacional de los predicados de RESPUESTA. La relación que estos verbos establecen entre el emisor-locutor y el receptor-interlocutor deriva su sentido de una anterioridad y de un movimicnto de inversión de la relación establecida en esta anterioridad. Esta dimensión reactiva hace que la acción de responder/contestar no puede aparecer en el momento inicial T1 de un discurso, sino que aparece necesariamente en un momento T2. Es una acción «segunda» o «derivada» que se caracteriza por formar la continuación, en T2, de una acción situada en el momento T1 en que cl actor-emisor de T2 aparece como rccipiente-receptor. $O$ sea, que como mínimo hay que imaginar una bidireccionalidad, que se puede obtener desdoblando la imagen como se propone en la figura 8.

4 Langacker (1991: 292-293) utiliza los términos «energy source» y «energy sink». 


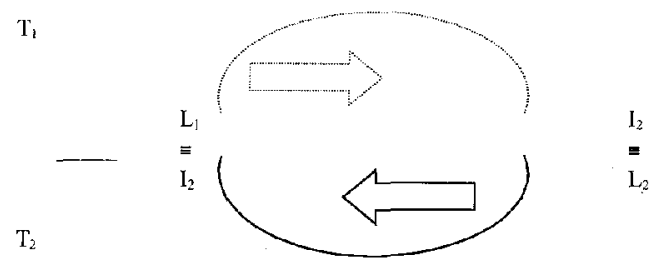

Figura 8. La gencración de un nuevo objeto semiótico en sentido inverso del primero

Así se ve que hay un punto de referencia causal inmediatamente externo que repercute en la nueva relación establecida en $\mathrm{T} 2$. La escena que forma la base del predicado de respuesta comprende en efecto un doble marco espaciotemporal: en $\mathrm{Tl}$ el respondiente/contestador ocupa la posición de «depósito de cnergía», o sea, de receptor, y la inversión de la direccionalidad en T2 implica que de receptor se convierte en emisor, mientras que otro elemento de $\mathrm{Tl}$ - sea el iniciador del primer evento, sea su producto, sea el evento mismo - llegan a ocupar la posición de receptor, pero no sin perder su valor de instigador primero de la acción en T2. Como en el marco $\mathrm{T} 1$ se perfilan dos entidades como trayector (el locutor X y su enunciado $\mathrm{p}_{-} \lambda_{\mathrm{X}}$ ), además de la pauta que es el receptor $(\mathrm{Y})$, y éste se convierte en trayector primario $\left(L_{t 2}\right)$ con como trayector secundario $\left(p_{-} \lambda_{\mathrm{Y}}\right)$-una entidad semiótica parecida al trayector secundario en $\mathrm{T} 1$ ( $\mathrm{p}_{-} \lambda_{\mathrm{x}}$ ) - este último es susceptible de transportarse como pauta al marco invertido en $\mathrm{T} 2$, en competencia con $\mathrm{X}$ (el primer emisor), que ahora se encuentra en el otro extremo de la dinámica de fuerzas. Significa que en vez de tres participantes que interactúan (como en los casos de transferencia y comunicación no marcados), hay que contar con cuatro. Además del locutor (L) y del interlocutor (I), no sólo cabe tener en cuenta las palabras $(\mathrm{p}-l)$ de respuesta/contestación que $\mathrm{L}$ producc en el acto de responder/contestar, sino tambićn las que le fueron dirigidas anteriormente por el interlocutor $\left(\mathrm{p}_{-} i\right)$. Es decir, que para ejecutar la acción, $L$ debe producir $p_{\_} \lambda$ interactuando no sólo con I sino también, crucialmente, con $p_{-} i$. Esto viene reflejado en la fórmula:

$$
\mathrm{L}\{\text { contesta/responde }\}\left(\mathrm{p}_{-} \lambda\right)\left(a \mathrm{I} / a \mathrm{p} \_\mathrm{i}\right)
$$

La inversión de los papeles puede proyectarse esquemáticamente sobre el eje temporal como sigue:

ACTO ESTIMULO

ACTO REACTIVO

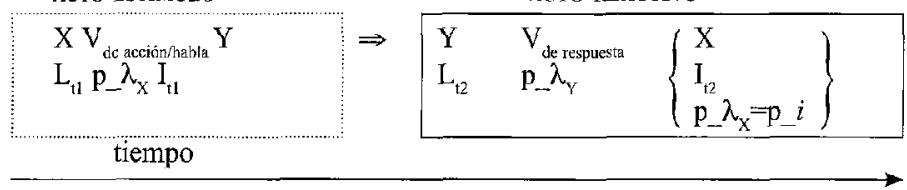

Figura 9. Posición en el tiempo de la respuesta como acto reactivo.

$\mathrm{X}$ e Y: los referentes; a la izquicrda de V: el protagonista; a la derecha de $\mathrm{V}$ : el antagonista; $\mathrm{L}$ locutor, I interlocutor, $\mathrm{p}_{-} \lambda$ las palabras de $\mathrm{L}$, $\mathrm{t}$ l y $\mathrm{t} 2$ : dos momentos sucesivos 


\section{El Marco conceptual de los prcdicados de RESPUPSTA}

Acabamos de ver que la proyección metafórica en términos de transferencia, comunicación y control claudica. En cambio, al situar la respuesta como acto reactivo sobre el trasfondo de un acto estímulo, se pueden molivar los fenómenos mencionados y algunos otros más. Como telón de fondo para la interacción hay que imaginar, por un lado, la superposición de papeles en las entidades $\mathrm{X}$ e $\mathrm{Y}, \mathrm{Y}$, por otro, las entidades semióticas en juego en la escena primaria y secundaria. Por otra parte, hay que adoptar el punto de vista de $\mathrm{Y}$, cs decir del $\mathrm{L}_{\mathrm{t} 2}$ que se encarga de la respuesta. Para este locutor, las palabras de $\mathbf{L}_{\mathrm{t} t}$, las de $X$ en $t_{1}$, son las palabras de su interlocutor $\mathrm{I}$, o sea, $\mathrm{p} \__{\mathrm{x}}$ equivale a $\mathrm{p}_{-} i$ o su contenido proposicional $\mathrm{p}^{\prime}-i$. Así se obtiene el espacio discursivo cuatripolar siguiente:

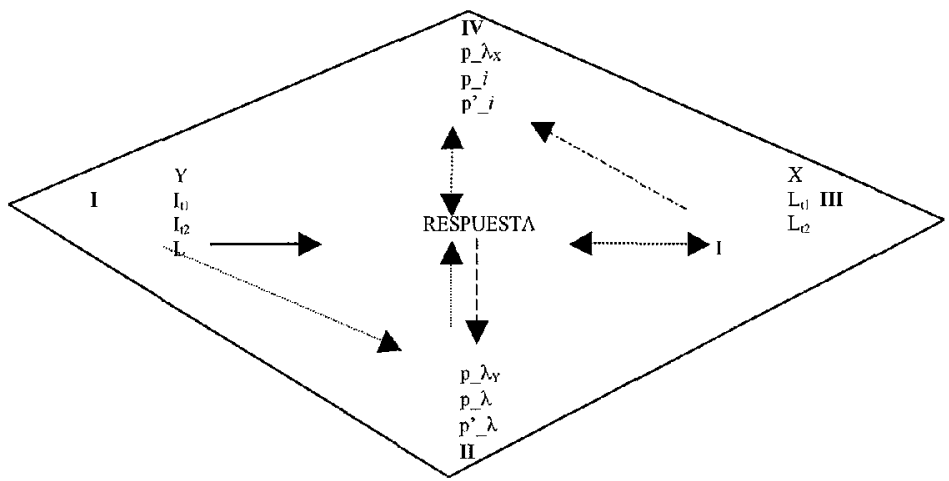

Figura 10. Espacio discursivo cuatripolar de los predicados de RESPUESTA

Bajo el supuesto de que a toda diferencia en forma de expresión de las entidades que ocupan este espacio corresponde una diferencia en significado, seguirá habiendo una base semántica común por un lado y, por otro, un abanico de perfilamientos diferentes de los papeles respectivos. Lo que unirá el conjunto de las construcciones de nuestros verbos es su proyección sobre este telón de fondo, en el que la dinámica de fuerzas reparte el control de la predicación entre dos actores alternativamente afectados ( $\mathrm{L}$ e I) y sus productos respectivos (p), por extensión metonímica susceptibles de conllevar el flujo de energía que emana de sus productores. La predicación - el ccntro de este cuadrilátero - se ve, pues, entrecruzada por cuatro fuerzas cuya distancia con respecto al centro puede variar, así como la proximidad entre ellas, según el grado de explicitud y las formas que toman.

\section{EXPLORACIÓN LÉXICO-CONSTRUCCIONAL}

La Gramática Cognitiva (Langacker 1987-1991) enticnde las construcciones como signos (asociaciones convencionales de forma y significado) integrados en una red de relaciones de herencia y motivación. En esta línea, la Gramática de Construcciones (Goldberg 1995) se ocupa de las estructuras sintácticas con el objetivo de definir el significado esquemático 
asociado con cada una de ellas. Las rutinas de interpretación que la estructura sintáctica añade arrojan luz sobre el potencial semántico del predicado verbal y de los participantes. ¿Cómo entender el alcance del significado impuesto por el esquema construccional? Si bien codetermina el sentido, la relación de determinación dista de ser unilateral: el que un lexema admita una construcción revela que tiene un significado compatible con el de la construcción. Por otro lado, los propios contornos de algunos esquemas construccionales no son siempre conceptualmente unívocos, como vimos en 3.3-3.4, por lo que hay que contar con la posibilidad de tener a veces estructuras eventivas mixtas. Además, los lcxemas también participan de una estructura scmántica reticular que les permite entrar en un abanico más o menos amplio de construcciones diferentes y asociarse de manera más o menos preferente con otros lexemas y catcgorías gramaticales (como tiempo y modo en el caso de los verbos). Cada entorno en que se presenta un lexema, cada elemento de ese entorno, puede precisar o matizar el significado que aporta el lexema en cuestión. Fsta visión composicional multidimensional tiene en cuenta no sólo el conjunto de construcciones posibles sino también la variación al nivel de los participantes y de otras categorías gramaticales, así como diferencias de frecuencia. A continuación me propongo explorar y comentar los puntos más llamativos. De paso mostraré que entre metáfora y metonimia, así como entre metáfora y generalización existen interacciones no siempre fáciles de definir.

Las construcciones no sólo se diferencian por el número y la forma de los argumentos, sino también por la posición que ocupan en el espacio discursivo cuatripolar esbozado en el apartado anterior, en combinación con su marco de referencia (universo humano, animal, semiótico, institucional, etc.).

\section{1. $\mathrm{N}_{0}$ [humano] le contesta / responde $\mathrm{N}_{1}$ [enunciado de $\mathrm{N}_{0}$ ] a $\mathrm{N}_{2}$ [humano]}

Por razones conceptuales (cf. 3.3.) puede considerarse como prototípica la estructura bitransitiva (10) en que $\mathrm{N}_{0}$ y $\mathrm{N}_{2}$ denotan respectivamente el locutor $\mathrm{L}$ y el interlocutor I (los polos I y III), y $\mathrm{N}_{1}$ el enunciado emitido (el polo II). De las tres posiciones argumentales, $\mathrm{N}_{1}$ es la más elaborada, salvo en interrogaciones, donde se encuentra focalizado el predicado (8). El discurso directo destaca el valor enunciativo de $\mathrm{N}_{1}$; no es raro que contestar vaya en inciso (19a). Con responder se acude más fácilmente a la subordinación sustantiva (21c) o una forma pronominal (11), o sea, formas en las que se difumina la diferencia entre lcctura de dicto y lectura de re. $\mathrm{N}_{0}$ no suele expresarse ni nominal ni pronominalmente y $\mathrm{N}_{2}$ sólo bajo forma clítica, lo que revela su estatuto altamente temático. Con contestar, las formas marcadas - ${ }_{0}$ expreso y $\mathrm{N}_{2}$ con duplicación clítica-; suelen ocupar las posiciones opuestas al lado del verbo, una como tema contrastivo, otra como foco. Al ser tematizado $\mathrm{N}_{1}$, puede volverse primaria la focalización de $\mathrm{N}_{2}(12)$. Lo habitual es situar en $\left[a \mathrm{~N}_{2}\right]$ el foco secundario, manteniendo $\mathrm{N}$ en posición final como foco primario. Al combinar las formas no marcadas de $\mathrm{N}_{0}$ y $\mathrm{N}_{2}$ con una simple referencia anafórica a $\mathrm{N}_{\text {}}$ se obtiene la focalización del predicado (20).

(19) a. - El padre siempre tiene razón - me contestaron-y te tienes que aguantar. (L. Herrero, 1991)

b. «Bueno, ¿y qué hacemos con esto de la triple alianza?». Entonces yo le respondi como el sereno de la Verbena de la Paloma: «Pues lo que te de la gana». (L. Herrero, 1991) 
(20) Eso le contesté y os juro que se quedó blanco cono la nieve. (J. García Hortelano, 1987)

Las divergencias observadas muestran que en contestar prevalece la dimensión enunciativa 'concreta' mientras que en responder se perfila más bien el contenido proposicional. Responder no sólo da paso a una lectura de re $\left(\mathrm{p}^{\prime} \_\lambda\right)$, también sugiere que el hablanteconceptor avala la respuesta y considera que $L$ reacciona de un modo satisfactorio a una pregunta formulada por I, o sea, que aporta la información deseada (cf. Wierzbicka 1987: 373). De ahí se infiere que la respuesta va en el sentido esperado por I (21a). Del contexto se deducirá si la sintonización es verdadera o fingida. El desdoblamiento en conceptor y actor es especialmente operativo en el discurso reproducido directa o indirectamente $(21 \mathrm{~b}, 21 \mathrm{c})$, donde L se muestra complaciente. En saludos, responder señala intencionalidad y control de parte de $\mathrm{N}_{0}(22)$, mientras que contestar sólo marca la reacción convencional (23).

(21) a. Le respondí que la familia, incluido yo, naturalmente, no hablábamos can Franco de esos asuntos. (L. Herrero, 1991)

b. Estoy por encogerme de hombros, pero reacciono a tiempo y le respondo: - Sí, por favor. Ya sabe que es para un regalo muy especial. Al ver que utilizo el mismo adjetivo que él, se sonríe de sus conocimientos en materia de palabritas. (C. Pérez Merinero, 1981)

c. Mi sonrisa se hace todavía más esplendorosa. - ¿Es suyo el coche? -insiste. Le respondo que sí, que claro que es mío. ¿Pasa algo? (C. Pérez Mcrincro, 1981)

(22) Cuando entro con la maleta en el edificio donde tengo alquilado un apartamento, el tonto del culo del portero - un chorbo que apesta a guardia civil retirado - me dice tan pelota como sicmpre con una sonrisa bobalicona y babeante:

- Bucnos días, don Ántonio.

- Hola, Paquito - le respondo - ¿Cómo va la cosa?

- Así, asi.

- Te quejas de vicio. Vives mejor que los frailes.

Fl se ríe y dice:

- Cómo es usted, don Antonio.

Don Antonio para arriba, don Antonio para abajo. Y yo, para joderle, Paquito por aquí, Paquito por allá. Pero al muy hijoputa le gusta. Hay genle que ha venido al mundo a poner el culo, y este mastuerzo es uno de ellos. (C. Pérez Merinero, 1981)

(23) Conchita llama con sus nudillos en la puerta del despacho de Rivera y se introduce en él. No tarda en salir acompañada del propio Rivera. Este, sonriendo, viene hacia mí y me dice:

- Buenos días, Domínguez.

- Buenos días, señor Rivera -le contesto yo.

Nos estrechamos la mano y me hace pasar a su despacho. (C. Pérez Merinero, 1981)

Ante peticiones (24a-b), amenazas (24c), tomas dc posición (25a), hesitaciones (25b), malas noticias (25c), la reacción $N_{1}$ es menos previsible, ya que puede estar en tela de juicio la cara de $\mathrm{N}_{0}$. Fuera de binomios rituales (pregunta informativa-respuesta, saludo) no bastan fórmulas de cortesía: dar la cara implica asumir cierto antagonismo y devolverle a $\mathrm{N}_{2}$ la pieza de su moneda aun si hay que llevarle la contraria. Esto tiene un coste: la modalización 
(deóntica en (24a), epistémica en (24b-c) permite atenuar la confrontación. En situación de debate, en cambio, donde es normal opinar y discrepar, aparecen focalizadores (mira (25a)) y marcadores metadiscursivos (en mi opinión (25b)) que refuerzan el impacto de la intervención. Cuando $\mathrm{N}_{0}$ se encuentra en posición de fuerza, puede actuar sin miramientos (Franco, muy contrariado, 25c). También es posible rectificar un planteamiento mediante simples relaciones antinómicas (bueno-malo (26a), madruga-trasnocho (26b)). La ironía y la burla también se revelan recursos eficaces en discursos (veladamentc) polémicos (27). Estas aplicaciones confrontativas forman la transición hacia el uso de contestar en marcos conflictivos (cf. Figura 4).

(24) a. - ¿Me echas una mano, Rosita?

Lc contestó una voz lejana:

— ¡No puedo, estoy ocupada! (F. Fernán-Gómez, 1985)

b. «En el siguiente filme -contaba el propio Leone- Eastwood me pidió que no le pusiera otra vez el cigarro, pero le contesté que no se podía hacer una película sin su protagonista, y Clint no tuvo más remedio que volver a fumar, al menos para el rodaje.» (ABC, 01/05/1989)

c. Para empezar, un pirado dijo que había venido allí a matarme. Lc contesté que era una posibilidad, sin duda, pero que no era probable que saliera ileso del todo, dada la muchedumbre allí existente. (F. Jiménez Losantos, 1995)

(25) a. Y yo le contesté; «Mira, Ramiro, si tú te leyeras la historia de Hitler y de otros persecutores de homosexuales, vcrías que casi siempre los que persiguieron a los homosexuales eran homosexuales». (TVE 2, 24/04/85)

b. Yo le contesté que, en mi opinión, debíamos llamarlc antes. El me respondió: «Bueno, que se le llame». (L. Herrero, 1991)

c. Franco, muy contrariado por lo que acababa de escuchar, clavó la mirada cn el ministro y le contestó: «Eso no es cierto y es muy grave lo que me dice». (L. Herrero, 1991)

(26) a. Luego que nos vio se adelantó para preguntarme: «i A estas horas vosotros por aquí, qué traéis de bueno?» Le contesté que todo era malo. (P. Ortiz-Armengol, 1994)

b. - Buenos días, señor. Madruga usted, — dijo el hombre del mostrador.

- No madrugo; trasnocho - le contesté. (E. Mendoఓa, 1975)

(27) a. "¿Y en qué programa?», les dije, y me contestaron: «iEn el que se elabore!» (L. Díaz, 1992)

b. Hace un par de semanas, en broma, un ministro me dijo: «A ver cuándo me piropeas»; yo, en broma, le contesté: «En cuanto dimitas.» (E. Romero, 1985)

En las pocas reformulaciones pasivas encontradas se procede a una generalización (siempre/ nunca, con agente sobreentendido) desde el punto de vista de N2 (me, 28a-b). Con contestar el objeto efectuado (N1) se mantiene en posición posverbal (28a), con responder cs cl propio predicado el que se ve focalizado (28b).

(28) a. Siempre se me ha contestado que eso no era cierto, que el Ministerio tenía verdaderos «records» de reuniones, trescientas no sé cuántas mesas, cientos de reunioncs, etcétera. (ABC, 11/03/1987) 
b. Varias veces he hecho estas proguntas... y no se me ha respondido. (ABC, 16/06/1996)

\section{2. $\mathrm{N}_{0}$ [humano] contesta / responde $\mathrm{N}_{1}$ [enunciado de $\left.\mathrm{N}_{0}\right]$}

Más frecuente que la construcción bitransitiva es la unitransitiva con $\mathrm{N}_{1}$ en forma de discurso directo o indirecto. La ausencia de $\mathrm{N}_{2}$ no significa que no haya destinatario, sino que no se perfila como receptor. Esto da paso a dos tipos de inferencias. Al no cerrarse la trayectoria de la respuesta, puede extenderse en todas las direcciones, do modo que el contenido proposicional de la subordinada sustantiva puede recibir un alcance mayor de cara a un auditorio plural o colectivo (29). En el contexto de un diálogo representado en discurso directo, en cambio, el interlocutor es pcrfectamente recuperable, pero no se le devuelve explícitamente el papel de interlocutor (30).

En términos metalingüísticos, esto cquivale a decir que la telicidad del movimiento será modulable según el contexto. Aun si prototipicamente parece ser condición sine qua non alcanzar la meta para hablar de un acto de RESPULSTA logrado, puede haber vaguedad al respecto, y tratarse de una acción o incluso una actividad frente a la que el papel del receptor puede convertirse en el de testigo, o su referencia puede volverse genérica.

Otra vez, la orientación axiológica parece ser distinta según el verbo: positiva con responder (29a, 30a-b), neutra, convencional o negativa con contestar (29b, $3 \mathrm{la}, 3 \mathrm{lb})$.

(29) a. Los defensores de Glenda responden que ha demostrado ser wuna política en serio». (ABC, 22/04/1997)

b. Un 11,6 por ciento, por el contrario, contesta que mejoró la imagen que tenía del cx jefe del Ejecutivo. (ABC 26/06/1997)

(30) a. Despierto a Willy, pues es su turno - Manu, estás temblando, te tiemblan las manos, ite ocurre algo? - me pregunta. - No, no cs nada, estoy algo destemplado - respondo. Cuando me meto en el saco de dormir me cuesta una hora conciliar el sueño. (M. Leguineche, 1995)

b. - ¿Por qué no me ayudas a levantar esta garrafa? — dijo la pianista.

- No faltaría más, respondí yo para granjearme sus simpatías. (E. Mendoza, 1975)

(31) a. - Salaam aleikum — dijo Don.

- Aleikum salaam - contestaron a coro todos los presentes.

- Coronel Reed, mi viejo amigo guerrero - dijo el jeque $\Lambda$ bdula sonriendo amistosamente- Sé bien venido a mi humilde campamento.

— Que Alá te protcja, Padre de Mubarak. (F. Schwartz, 1982)

b. Esa noche deshinchamos las ruedas de los jeeps cono represalia. Temerosos de que la protesta social fuera a más, los chinos se avinieron a negociar.

-Diez bat más al día - me ofreció mister Kuang.

- Es una miseria, no hay trato - contesté. (M. Leguincche, 1995)

\section{3. $\mathrm{N}_{0}$ [humano] contesta / $\mathrm{N}_{0}$ [humano / propiedad humana] responde}

A diferencia de los predicados de transferencia (dar, decir), los verbos de respucsta también pueden construirse sino otro participante que el sujeto. La interpretación genérica 
que conlleva la construcción absoluta recae de forma diferente en $\mathrm{N}_{0}$ según que se emplee contestar o responder. En contextos temporalmonte no restrictos contestar se interpreta como iterativo (32c), pero los (ma) logros guardan el carácter enunciativo reactivo, puntual y efimero que tienen en contextos temporalmente restrictos (en esta ocasión (32a), de momento (33b)), o sea, que suponen un interlocutor inmediato y cmanan de un emisor cuya denotación puede ser metonimica (una voz lejana (24a)).

Con responder el alcance de la «respuesta» transciende el marco dialogal: (i) su funcionalidad estriba en objetivos más generales, (ii) puede expresarse por canalcs otros que lingüísticos o acústicos, (iii) no se dispara sólo a partir de un acto enunciativo, (iv) sino que puede ir motivada por un estado de cosas o una pluralidad de eventos, (v) su manifestación no es restricta en el tiempo, y (vi) su adecuación depende más del perfil de $\mathrm{N}_{0}$ (el polo I de la figura 10) que de la similitud o complementariedad de su acción (el polo II) con un evento anterior (el polo IV). Trátese de espectadores (34a), jugadores (34b-c, 36b) u obispos (36a), «responder» es señal de vigor: presenta a $\mathrm{N}_{0}$ como merecedor del nombre que lleva. Cuando en $\mathrm{N}_{0}$ se menciona un órgano (corazón (35a), la voz (35b)), su comportamiento se evalúa tanto en términos de competencia simbólica como de eficiencia física.

(32) a. Fn esta ocasión contesta el embajador, Henning Wegener. (ABC, 26/05/1997) b. - ¿Y aceptará Chicho? - De momento no se sabe, no contesta. (ABC, 28/04/1986)

c. Tu padre te coge la maleta, la Abuela cstá más acelerada que de costumbre y Quico también anda nerviosete. Mientras coméis, llegan unos y otros; saludas, preguntan, contestas y, como es de cumplido en eslos casos, se sientan a un lado, silenciosos y sin perder un detalle, mientras vais comiendo alrededor de las trébedes. (A. Berlanga, 1984)

(33) a. Pizarro: Es muy sencillo: cuando Escobar os interrogue, respondéis con cvasivas, como si lo que en verdad os preocupara fuera mantener el secreto. (A. Vázquez Figueroa, 1993)

b. Yo frente al odio cicgo respondo con el resentimiento. (M. Martínez Mediero, 1982)

c. A vuestra fe y a vuestro fanatismo respondo yo con el mío. (I.M. Gironellat, 1986)

(34) a. - Hay quien habla de crisis de público.

- No existe tal crisis, como lo prueba el hecho de que cuando se ofrecen montajes atractivos y bien hechos, los espectadores responden. Ahí cstán los casos de «Luces de Bohemias, que hemos debido reponer en el María Guerrero ante la demanda existente, y el de "La casa de Bernarda Alba». Fil público va al teatro cuando tiene garantías de que lo que se le ofrece es un buen producto. ( $\Lambda \mathrm{BC}, 03 / 06 / 1985)$

b. Cuando las piernas fallan, ni hombres como Guardiola, Kiko, Raúl o Alfonso responden. ( $\mathrm{ABC}, 09 / 06 / 1997)$

c. «Un delantero que comprueba cómo sus compañeros de la defensa responden, que no se reciben goles y que se crcan ocasiones, sabe que el gol tarde o temprano tiene que llegars (ABC, 04/06/1989)

(35) a. Pero, en tu caso, ha sido tu propio corazón el que ha respondido y servido con devoción. Tú también vendrás un día a servir a mi lado $\mathrm{cn}$ cl reino eterno. (J.J. Benitez, 1984) 
b. Yo cuando escucho un sonido emitido por una voz, sć de dónde está saliendo, de qué parte de la de de la garganta está salicndo, con lo cual es su imitación a mí me resulta muy fácil. Y, además, como la voz responde, pues todavia más fácil. (Radio, Madrid, 20/12/91)

(36) a. Los obispos responden con claridad no exenta de matices. (ABC, 04/10/1982) b. Quizá por encontrarse con un público que le apoyó siempre y con una pista que anima a hacer buen baloncesto. Pinedo ha movido muy bien a sus hombres - cada dia con un cinco inicial distinto-- y éstos han respondido plenamente. Al final, hasta el «junior» Arévalo logró dos puntos frente a los facilones brasileños. $(\Lambda \mathrm{BC}$, 26/12/1982)

c. Él respondió con un breve discurso, muy enjundioso, que llevaba aprendido de memoria, y que recitó sin un traspié, con aquella vaz suya, tan de superior, tan pastosa y agradable. (G. Torrente Ballester, 1988)

Con responder, se entiende por defecto que se reacciona como lo requiere la situación, cs decir, de manera 'responsable'. De ahí que posibles elaboraciones suelan ser de tipo evaluativo (con claridad no exenta de matices (36a), plenamente (36b)) y señalen la fuerza, intencionalidad y carga subjetiva (con devoción (35a), con evasivas (33a), con el resentimiento (33b)). Refuerzan la relación de contigüidad entrc los polos I y II del diagrama 10 , por lo cual tienden a fundirse, a identificarse uno con otro, tipo de respuesta y tipo de locutor. Cuando la valoración remite al formato de la respuesta (con un breve discursa... (36c)), el objeto semiótico producido se ve como la emanación protética del locutor, toda orientada hacia el resultado y la acogida positiva de su contenido. En cambio, precisiones relativas al modo de ejecución (sin un traspié, con aquella voz... (36c)) se apoyan más bien en predicados enunciativos (recitó). Contestar es uno de ellos: sólo denota que se toma cl turno de habla, independientemente de la cuestión de saber si el contenido es el adecuado o no. Sus adjuntos se interpretan en función del acto que suscita la 'contestación' e inciden en cl modo de enunciación (en voz alta (5b), a coro (31a), con un gruñido (37a)) o la representación subjetiva del papel de enunciador (en broma (27b), con un poquito de orgullo (37b)).

(37) a. - Carlos. Despiértate, que son las dos.

Abro los ojos con cierta dificultad y contesto con un gruñido.

- Sí, sí, siempre ahora voy, ahora voy, pcro hasta que no se os saca de la cama, nada. (J.A. Mañas, 1994)

b. Recuerdo que uno de ellos me dijo: «¿Sabe usted lo que es una isla?». Contesté. «Pucde usted darme el nombre de ulguna isla española?». Y entonces yo con un poquito de orgullo contesté, porque no creo que muchos pudiesen hacer lo que yo hice. $Y$ es que di una cantidad enorme de lis de una lista enorme de lis de islas españolas que yo había pisado. (Entrevista, Madrid, 1981)

\section{4. $\mathrm{N}_{0}$ [humanol $\left(\mathrm{N}_{2}\right.$ [clítico dativo]) contesta $\mathrm{N}_{1}$ [la pregunta/ el saludo de $\left.\mathrm{N}_{2}\right]$}

El que en vez del objeto efectuado (el polo II de la figura 10) $\mathrm{N}$ también pueda denotar el objeto afectado (el polo IV) corrobora la pertinencia de este último como acto disparador: además de preguntas (38a), se contestan encuestas (es decir, series de preguntas (38b)) y saludos (38c), o sea, entidades que operan a modo de incentivo y a cuyo contacto se requiere 
una reacción inmediata, convenientemente codificada. Con su acto de habla, $\mathrm{N}_{0}$ se muestra receptivo a la división de trabajo implicada por el estímulo: a uno le toca preguntar, a otro contestar (39). La reacción de $\mathrm{N}_{0}$ es ritual, convencional, socialmente conforme. Cumple con los principios de cooperación y cortesía (cf. la tradición del análisis pragmática desde Grice 1975 y Brown \& Levinson 1987). La atención se centra en el acierto (38) o los buenos modales (39) de $\mathrm{N}_{0}$ (el polo II), que sale mecánica o automáticamente a la demanda, venga ésta de quién venga. De ahí que $\mathrm{N}_{2}$ (el polo IIl) sucla quedar sobreentendido. Al no ser así, sólo aparece en forma deíctica débil: sea como adjetivo posesivo incorporado a $N_{1}$ (mi pregunta (38a)), sea como clítico (40). En combinación con la pregunta (40a-b), el dativo posesivo actualiza el estatuto de interlocutor $(\mathrm{I})$, no su función antecesora $\left(\mathrm{L}_{\mathrm{t} 1}\right)$. Es un recurso para obtener una escena dinámica sin que la interacción se vuelva conflictiva. Se obtiene, sin embargo, un enunciado más inquisitivo al vincular expresamente interlocutor e interrogantc (los polos III y IV: me... mi pregunta (40c)), o al hacer asumir cl papel de interlocutor (polo III) reflexivamente al propio referente del sujeto $\mathrm{N}_{0}$ (polo I) (se... usted (40d)).

(38) a. Todos en pie para la despedida, recordé que Paroise no habia contestado mi primera pregunta. (J.A. Vallejo-Nágera, Yo, el rey, 1985)

b. Fin la primera sesión, de evaluación, los alumnos cuntestaron la encuesta y realizaron la prueba de monóxido de carbono. (E. Becoña, 1994)

c. Enriquín: ¡Hola!

Vecino: Buenas tardes, doña Elisa (Les contestan el saludo) ¿No está Miguel? Abuela: No tardará mucho. Ha ido aquí al lado, (...) (F. Cabal, 1979)

(39) a. Él, al parecer, está para hacer las preguntas y yo para contestarlas. Creo que a eso los letrados le llaman la división del trabajo. Así que el hijoputa no me responde, sino que dice:- ¿Por qué ha aparcado aquí? Le contesto que me estaba meando. Lo digo en francés y el tío no caza la cosa. (C. Pérez Merinero, 1981.)

b. No, perdón, contesto la pregunta. Sen̂or Mendoza, perdone. Aquí el que modera soy yo. (Telemadrid, 08/04/91)

(40) a. ya le ha contestado la primera pregunta (Televisión, Madrid, 21/12/91)

b. ya, casi casi, la pregunta me la ha cuntestado (Radio, Guadalajara, 22/01/90)

c. Pcro no me ha contestado usted mi pregunta, el porqué de su asalto directo, predisponiéndome a colocarme a la defensiva. (M. Vázquez Montalbán, 1990)

d. ¿Se ha contestado usted alguna vez esta pregunta, profesor? (M. Vázquez Montalbán, 1990)

El esquema $\left.\left[\mathrm{N}_{0} \mathrm{~V} \mathrm{~N}_{1(\text { a picgunta }}\right)\right]$ es muy excepcional con responder, y va sin dativo. De motivo inicial, la pregunta se convierte en problema por tratar, ya no como materia ajena, sino como planteamiento propio. $\mathrm{N}_{0}$, en $1^{\mathrm{a}}$ persona, no está evaluando su comportamiento en cuanto reacción lograda, sino en cuanto Iratamiento de un tcma (41). La presencia de la preposición $a$ en el contexto inmediato atenúa la diferencia con el esquema canónico (ya aparece al final de (41b); es presentado en $5.12 ;$. $^{5}$

5 En (27a) el antecedente de $\mathrm{N}_{1}$ lleva $a$, en $(27 \mathrm{~b}) \mathrm{N}_{1}$ va precedido de una modificación adverbial introducida por $a$ (a medias). 
(41) a. Mc parece que es un buen momento, no para que yo cietre el tema, sino justamente para abrir el tema a una pregunta que no hemos respondido nunca: ¿Qué comunidad es la que queremos? Pregunta que va en la linea de estas conversaciones y con el debate de la Escuela Una. (Conversación, Granada, 2000)

b. ¿Cree usted realmente en todo lo que dicc?, me interrumpe, mirándome a los ojos.

Me siento desconcertado, sin sabcr qué responderle. Enrojezco y desvío la mirada. No esperaba que los tiros viniesen de esa dirección. Consigo por fin decirle que sí, que comprendo muy bien que los hombres, al margen de su edad, pierdan el seso por un par de piernas bonitas. De esa forma, sin embargo, sólo respondo a medias su pregunla y no le convenzo.

En realidad, no hubiera podido convencer a nadie. Mueve la cabeza de izquicrda a derecha y opina que un hombre como yo no debicra de hablar de ese modo, ni recurrir a tantos tópicos.

Al fin y al cabo (añade, justificando su obscrvación) usted no ha tenido nunca una mujer entre los brazos.

No me parce justo lo que está ocurriendo. Entré en este despacho para pedir un empleo y tratar de responder honestamente a todas las preguntas que me hiciesen, no para someterme a una sesión de psicoanálisis. Hay situaciones, de cualquier modo, ante las que un hombre no puede permanecer cruzado de brazos, así que alzo la frente, decidido a jugármelo todo a una carta. (Javier Tomeo, Amado monstruo, 1985)

\section{5. $\mathrm{N}_{0 \text { [figura pûblica / institución] }}$ ])] \\ contesta $\mathrm{N}_{1}$ [las palabras, la decisión, la poltitica (de $\mathrm{N}_{2 \text { [igura públiea }}$}

El mismo esquema da lugar a una aplicación contestataria, o sea, polémica. La polarización se explica por el paso del marco interpersonal al institucional. Sin embargo, sigue en pie la equiparación funcional de $\mathrm{N}_{0}$ con $\mathrm{N}_{2}$ : lo que hace $\mathrm{N}_{2}$ (polo III-IV) determina y legitima la reacción de $\mathrm{N}_{0}$ (polo I-II). En el caso no marcado (5.4), el papel de interlocutor asumido por $\mathrm{N}_{0}$ se justifica por convenciones gencrales de convivencia: una pregunta supone el derecho a la información y un saludo la reciprocidad. No contestar es faltar a expectativas socialmente codificadas. Contestar es scguir las reglas del juego y mostrarse a la altura. Mutatis mutandis operan los mismos mecanismos en la organización de la sociedad: si bien uno no recibe su turno como en los intercambios verbales de la vida cotidiana, también conviene que sepa exactamente cuándo le toca intervenir y dar la cara ante la jugada de un rival si quiere ser tomado en serio como homólogo. O sea, que en el terreno del reparto del poder cntrc actores sociales también funciona un sistema de intercambios codificado (cf. Bourdieu 1982).

El que la movida lleve el signo de la contraposición se explica por las características del marco de referencia o frame (cf. Goffman 1974). La gestión y defensa de las ideologías e intcreses de grupos se delega a actores sociales (figuras públicas e instituciones). Fsto entraña la parcelación del espacio colectivo en dominios de influencia que actores sociales rivales se disputan entre sí. En este marco, mostrarse receptivo a los estímulos y reaccionar consecuentemente implica ir públicamente a contracorriente de un rival, o sea, poner en tela de juicio su actuación. El perfil de $\mathrm{N}_{2}$ (polo III) no sólo determina el impacto de $\mathrm{N}_{1}$ (polo IV) sino que también impone restricciones al perfil de $\mathrm{N}_{0}$. Para ser efectivo, $\mathrm{N}_{0}$ debe aportar un contrapeso, es decir, poner en la balanza un peso comparable al que tiene $\mathrm{N}_{1}$ y apoyarse en 
la misma legitimidad que $\mathrm{N}_{2}$. De ahí que los antagonistas se muevan cn el mismo terreno y a niveles comparables: presidente del mayor partido de oposición vs. presidente de gobierno (42a), órganos de prensa de obediencia opuesta (42b), institución defensora de los intereses de los empleados vs institución empleadora (42c).

(42) a. En este sentido, el presidente del PP, José María Aznar, afirmó aycr en la cadena Ser que «España se limpiará de conupción cuando se produzca un cambio politico». También, para contestar las palabras el martes de Felipe Gonzálcz de que con la detención de De la Rosa se acaba la cultura del «pelotazo», el líder popular señaló que «la cultura del 'pelotazo' no nace porque sí, hay una inspiración, alicnto y amparo desde el poder y el Gobiemo (...) (La Vanguardia, 20/10/1994)

b. Esta Oficina de Prensa ha contestado reiteradamente la polílica informativa del periódico EL PAÍS y de su corresponsal en Bilbao, a raíz de la campaña contra la Ertzaintza, dirigida en realidad contra el consejero Retolaza, estos últimos tiempos. (E1 País, 01/12/1987)

c. Cabe señalar, finalmente, la reacción ante la postura del arzobispado en los medios de extrema derecha. El Alcázar, órgano de los combatientes, ha contestado la decisión con notable dureza. (El Pais, 10/11/1976)

Un $\mathrm{N}_{0}$ como decisión judicial (42) perfila la legitimidad y efectividad de agentes humanos (el juez) o colectivos (la Justicia) (polo I). Comprueba pues que éstos son asimilables a su actuación (polo II).

(43) Esta decisión judicial contesta el recurso planteado por el Instituto Nacional de Empleo (Inem) hace dos meses contra la sentencia de la Magistratura de Trabajo de Murcia que condenaba a dicho organismo al pago del seguro de desempleo agrario. (El País, 01/06/1987)

\section{6. $\mathrm{N}_{0}$ [humano / institucional] contesta a $\mathrm{N}_{1}$ [humano / institucional]}

La estructura biargumental de contestar que relaciona dos participantes humanos no sólo permite lecturas más o menos confrontativas; su perfil también oscila en términos de funcionalidad según que $\mathrm{N}_{1}$ se marque anafóricamente (5.7) o no (5.6). Sin duplicación clítica se obtiene una visión 'institucionalizada'. En posición posverbal, no tematizada, el destinatario destaca como el blanco que $\mathrm{N}_{0}$ toma como punto de referencia. A veces se pone en cvidencia el objcto en litigio (el polo II) como tercer argumento en posición final ((44), cf. 5.1).

La (a)simetría entre los estatutos de $\mathrm{N}_{0}$ y $\mathrm{N}_{1}$ determina la orientación pragmática. En una relación asimétrica a favor de $\mathrm{N}_{0}$ la actuación encaja en su ejercicio del poder (45b). En una relación simétrica $-\mathrm{N}_{0}$ y $\mathrm{N}_{1}$ están en pie de igualdad- $\mathrm{N}_{0}$ da una contrapartida ritualmente codificada, e.g. en un acto oficial (45a). En cambio, al estar indecisa la balanza, $\mathrm{N}_{0}$ se afana por afirmarse para rebajar el impacto de $\mathrm{N}_{1}$ y (re)equilibrar la relación. En la medida que esto equivalga a interpclar la posición simbólica de $\mathrm{N}_{1}$, es una dinámica que lo convierte virtualmente de destinatario en paciente, asemejándolo hasta cierto punto al acusativo preposicional con verbos del tipo combatir, criticar, censurar, aplastar, herir, matar (cf. Delbecque 2002: 103 ss.). En (46) es decisión diplomática de los consejcros de Don Juan no quedarse acallados ante la prepotencia de Franco, salir al encuentro de una contienda, asumir el papel de contra-agente. Aun cuando el estatuto de $\mathrm{N}_{0}$ es jerárquicamente inferior 
al de $\mathrm{N}_{1}$, contestar expresa la voluntad de $\mathrm{N}_{0}$ de ponerse a la altura de $\mathrm{N}_{1}$. En la medida que $N_{1}$ goza un estatuto que impide su 'pacientización', la interpretación de la forma oblicua [a $\mathrm{N}_{1}$ ] no sc deslizará hacia el ámbito del acusativo, o sea, que no rebasará los límites del dativo (Delbecque \& Lamiroy 1996).

En ausencia de clítico la escena no se centra en la interacción de persona a persona sino en el reparto de los roles sociales. El carácter atinado de la actuación reactiva de $\mathrm{N}_{0}$ (polo I) se mide en función del poder institucional del instigador primario $\mathrm{N}_{1}$ (polo III). Este esquema construccional no se da sólo con nombres de organizaciones (PSOE (44)) y nombres de oficio (académico (45a)), sino también con nombres propios que identifican a personajes de la escena pública (Franco (46), don Fernando (47b)) e incluso con nombres relacionales (padre (47a)). Si bien la lectura 'social' de estos últimos suele ir incluida en la denotación de la persona, se acude a esta construcción para marcar su rol y evocar comportamientos que desvían respecto de lo socialmente espcrado, como lo corrobora la interrogación (ipor qué?) y la referencia anafórica (asi) en (47a).

(44) El Gobieno contesta al PSOE: «La Ley de TV Digital ha evitado un monopolio de facto* (ABC, 29/04/1997) (Ejemplo del tipo 5.1)

(45) a. Es el turno de Emilio Lledó, que contesta al nuevo académico. (ABC, 02/06/1997)

b. Sobre el tema de las inhabilitaciones. El Gobierno contesta al senador socialista (ABC, 18/05/1982)

(46) Sainz Rodríguez envía un informe al Rey con el leoncito de lacre: «Lo que quiere Franquito es que Vuestra Majestad se calle. Así que lo que ticne que hacer es hablar enseguida. Lo tenemos bien jodido.» $\mathrm{Y}$ al no recibir respucsta, fuerza una conversación telefónica. Gil-Robles le respalda. Vegas y López Oliván también. Se toma la decisión de contestar a Franco y haccr declaraciones públicas. F. 25 de enero de 1944, el Rey firma una carta escrita por López Oliván y aprobada telefónicamente por Sainz. En ella dice lo que piensa, cosa excepcional en la correspondencia delirante entrc Franco y Don Juan en la que se mienten uno a otro, sin otro objetivo que el de mcjorar sus posiciones en la lucha por el poder. (L.M. Anson, 1994)

(47) a. Luis (Presa de una rabieta tremenda, interrumpe a su padre): ¿Ves? ¡Ya cstás con tus cosas! ( $Y$ se marcha del comedor)

Doña Dolores (Va hacia la puerta y habla desde allí): ;Luisito! ¿Por qué contestas así a tu padre?

Voz de Luisito: ¡Si no me he cnfadado, mamá! ¡Es que es ya la una y media! ¡Se me ha hecho tarde!

(F. Fernán-Gómez, Las bicicletas son para el verano, 1982 (teatro))

b. He contestado a don Fernando dos días después de haber sido leída públicamentc su carta. El emperador desaconsejó hacerlo antes, como yo deseaba. (J.A. VallejoNágera, 1985)

\section{7. $\mathrm{N}_{0}$ [humano] le contesta a $\mathrm{N}_{1}$ [humano]}

Sin clítico predomina la vertiente funcional (5.6). Cuando $N_{1}$ se aborda de manera holística, o sea, integrando su posible papel en una visión encarnada plena, es habitual que haya 
clítico dativo. Éste puede ser tomado como criterio de la posición nuclear del participante en el evento (48). La reciprocidad de $\mathrm{N}_{0}$ a $\mathrm{N}_{1}$ puede manifestarse por voces ecoicas (aleikum salaam (31a), vociferante... insulte (48b)); de ahí que contestar se aplique por extensión al mundo animal (ladró (48c)).

(48) a. ¿No me contestas, hijo mío...? (M. Martinez Mediero, 1991)

b. No quiero toparme con un borracho vociferante y que me insulte en plena calle. ¿Qué hago? ¿Le contesto? ¿Qué tiene que perder un borracho? ¿Qué tiene que ganar? Mucho. Lo que uno pierde el otro lo gana, así que es mejor no darles oportunidades. (V. Chamorro, 1984)

c. Llegaron al arcén y Prada miró hacia el terraplén. Un perro flaco ladró y le contestaron otros. Miguel se metió dos dedos en la boca y emitió un largo y penetrante silbido. (J. Madrid, 1989)

Discursivamente, el clítico le señala el carácter tematizado de $\mathrm{N}_{1}$. Lo cual supone que se particularicc su referencia. Se refuerza, pues, su perfil humano, o sea, que se le "personaliza'. Esto da lugar a un evento mixto en el que la percepción global de $\mathrm{N}_{1}$ puede competir con su papel interlocutivo $\left(a N_{1}\right)$ definido por un oficio o cargo institucional. Si el sintagma preposicional se considera coextensivo al clítico correferente, éste se deja analizar como la realización duplicada del dativo (compárese (49a) con (47a)). En cambio, si $\left[a \mathrm{~N}_{1}\right]$ no se concibe como coextensivo sino que sólo representa una vertiente funcional dcl referente del clítico, estamos ante una relación parte-todo. Así, en (49b), el clítico dativo remite a la persona en su globalidad, mientras que a un juez perfila oblicuamente el rol que desempeña. Esta disociación entraña la ambivalencia entre el respeto de la cara del otro -al (re)actualizarse su estatuto de persona (le), es interlocutor válido al mismo título que $\mathrm{N}_{1}-\mathrm{y}$ su interpelación en cuanto actor social. Habitual con nombres de oficio, la distinción rol vs. persona puede desteñir sobre nombres relacionales (padre, madre, hijo, hermano, tio, etc.); esto significa que hasta un ejemplo como (49a) puede resultar hasta cierto punto ambivalente en la medida que la relación de hijo a padre es susceptible de instrumentalizarsc como la de un alto cargo a un juez. Metafóricamente, la 'segunda piel' que uno reviste lo localiza e identifica de la misma manera que lo puede hacer el tipo de lugar en que se encuentra (los distintos puertos (50)).

(49) a. Mary: Nosotras hemos fracasado. Ni las lágrimas ni las amenazas han servido. A su padre ni siquiera le ha contestado.

Marta: Le desprecia. Ni te ha mirado. Te ignora por completo. (M.M. Rcina, 1990)

b. «Cuando un alto cargo que no está aforado no le contesta a un juez y dice que no da documentación por el secreto profesional, yo creo que debería dormir provisionalmente en la cárcelm. (El Mundo, 31/03/1995)

(50) Sea como fuera Claudio $Z$. anduvo cmbarcado durante medio año y su única relación con su familia fueron las cartas que escribía a su madre, que le contestaba a los distintos puertos que tocaba el carguero. (J. Alfaya, 1991) 


\section{8. $\mathrm{N}_{0}$ [humano] contesta a $\mathrm{N}_{1}$ [preguntus, llamadas, mensajes, peticiones, criticas, ata- ques $\left(\right.$ de $\left.\left.\mathrm{N}_{2}\right)\right]$}

La entidad que ocupa la posición oblicua en el esquema biargumental es más a menudo la que se sitúa en el polo IV de la figura 10. El que incluso los lexemas pregunta y saludo suelan llevar a muestra que el locutor $\mathrm{N}_{0}$ no se deja simplemente llevar por la lógica de la situación. En vez de tomar la pregunta o el saludo irreflexivamente como objeto de acción, los perfila como el término de su respuesta concebida como movimiento orientado. El oblicuo vincula el agente $\mathrm{N}_{0}$ (polo I) de forma menos cstrecha con el estímulo (polo IV): en vez de ir pegado al evento anteccdente, la contestación se concibe como un movimiento libremente asumido, orientado hacia una señal de la que sólo emana una interpelación virtual, o sea, que no exige reacción o devolución inmediata (51).

(51) a. Sobre Santiago Carrillo: «Es un lider habilisimo que sc ha situado con extrema pericia bajo una luz que le hace parecer muy responsable, y ello, sin embargo, sin cambiar para nada la estructura interna del partido ni las formas en quc le gustaría gobernar si ocupase el Poder.» Carrillo contesta a ello en unas declaraciones al corresponsal de la N. B. C. en Madrid: «Todo el mundo tiene derecho a la duda. Yo dudo de Nixon y de Kissinger. Pero hay una garantía que (...).» (ABC, 14/01/1978) b. Enrique: Susana, dime, ¿qué sabes?

Susana: Menos que tú.

Enrique: ;Adelante!

Susana: Casó con tu madre antes de la guerra, vivió pocos años con clla, parece que la quiso.

Enrique: Lo que pregunto está más próximo, sale de tu convivencia con mi padre. $Y$ a eso no contestas.

(R. Gil Novales, 1979)

La diferencia con el esquema transitivo directo se manifiesta en (52). Primero se introduce genéricamente la actividad orientada hacia el estímulo (contestan a mensajes), luego se pasa a la aplicación personal en que uno de esos estímulos se convierte en dominio de aplicación (el que yo contesté), o sea, que el objeto afectado se integra en el dominio de la entidad sujeto (cf. 5.4.).

(52) ¿Qué pasa, que antes de los veintitantos claro, los jovencitos no se atreven diccisietc, dieciocho hay chicas asi jovencitas, diecisćis, diecisiete, que si que contestan a mensajes. En concreto, el que yo contesté primero, otras chicas contestaron también y eran más o menos de esa edad. (Tele 5, Madrid, 17/01/92)

El carácter no rutinario se corrobora por el perfil inhabitual de $\mathrm{N}_{0}$ (chicas asi jovencitas (52), noctámbulos y madrugadores (53a)), la determinación con que se contesta (si que (52), con excesiva energía (53b)), y/o el carácter no impositivo del estímulo de contornos a menudo poco precisos (a ello (51a), a eso (51b), mensajes (52), hace flamear la bandera azulgrana (53a), aun lejos... alzó la mano (53b), que no iba dirigido a ella (53c)).

(53) a. Todavía no han puesto las calles y Mariano ya hace flamear la bandera azulgrana en la parada del Tombús de la plaza Catalunya. Noctámbulos y madrugadores con- 
testan al saludo. Mar y Tere detienen un momento el coche para transmitirle su mensaje de aliento: - ¡Diles que no vuelvan sin la copa! (La Vanguardia, 19/05/1994) b. Luego retomó su copa y esperó, temblándole las manos, hasta que, aun lejos pero ya bien delineados los cuerpos a la vista, Teresa alzó la mano y le saludó y luego los otros dos y él contestó al saludo con excesiva energia, esperó a que llegaran, besó convencionalmente a Teresa y se dirigieron a los coches. (J.M. Guclbenzu, 1981)

c. Dicen que después de aquel recibimiento nunca más quiso salir a la calle. Unos piensan que de vergüenza por haber contestado a un saludo que no iba dirigido a ella, otros que de dolor... (J.P. Aparicio, 1989)

A diferencia del régimen directo el oblicuo da cabida a entidades que no constituyen por definición una invitación a reaccionar (un comentario (54), las críticas de J. Habermas (55a), las injurias que se decian de mí (55b)). El contexto de (54) ilustra que la reacción se percibe como una iniciativa de cierto alcance.

(54) Carlos.-Creo que has sido demasiado rotunda.

Rebeca-- Sólo he contestado a un comentario.

Luis.-- Esa contestación te la podías haber callado.

Rebeca.- Yo pensaba que ésta era una reunión de amigos.

Daniel.- No te preocupes, querida. Daremos la respuesta por no escuchada.

Rebcca.- No tengo prejuicios. He venido dispuesta a no quitarme cl «también» de la boca.

(R. Mendizábal, 1992)

(55) a. En la siguiente entrevista expone algunos aspectos de su reflexión sobre la actualidad y contesta a las criticas de Jurgen. Habermas. ( $\Lambda \mathrm{BC}, 28 / 05 / 1989)$

b. Es por esto que dicen que mi carácter es frío y por lo que mis detractores estaban tan desorientados, porque nunca grité ni conlesté a las injurias que se decían de mí. (C. del Val, 1998)

En esta estructura eventiva el origen de la acción antecedente (polo III) no recibe estatuto argumental, o sea, no compite por el protagonismo. Sin embargo, se incorpora a veces en el argumento oblicuo (polo IV). Así se realza el carácter público o profesional del escenario (el presidente del Cabildo Insular (56a), el pintor Van Doesburg (56b), la Redacción de $A B C(57 b)$ ). La legitimación de $\mathrm{N}_{0}$ a su vez proviene del rol u oficio en virtud del cual contesta (director (56a), el pintor Mondrian (56b), obispo (57b), etc.)). El protagonismo de $\mathrm{N}_{0}$ es mayor que en la construcción transitiva directa: ahora está capacitado para contestar a peticiones y solicitudes (56), le es permitido dejar pasar cierto tiempo antes de contestar incluso a preguntas (en un posterior coloquio (57a), no... todavia (57b)). Su legitimidad o competencia para contestar puede ser comentada (en vez del alcalde (58a)) o puesta en tela de juicio (54). En (58b) la alternancia entre contestar (400 opositores) y responder (el 10 $\%$... correctamente) refleja el paso del dominio de la participación legal al de la evaluación del acierto individual. Una rara vez se despersonaliza $\mathrm{N}_{0}$; si bien se remonta por vía metonímica de las interesantes teorias (59a) a los cicntíficos que las diseñaron, es una manera de mitigar la falta de capacidad. 
(56) a. El director de la Real Academia Española de la Lengua ha contestado a una petición formulada por el presidente del Cabildo Irsular de Gran Canaria, de manera afirmativa, para inchir el gentilicio grancanario/a en el diccionario. (Canarias 7 , 19/09/1996)

b. A la solicitud de Van Doesburg Mondrian contestó negativamente (C. Crcgo Castaño, 1997)

(57) a. García de la Torre contestó a numerosas preguntas de los estudiantes en un posterior coloquio. ( $\mathrm{ABC}, 29 / 01 / 1985$ )

b. El obispo de San Sebastián no ha contestado todavía a la pregunta que le formuló la Redacción de $\mathrm{ABC}(\mathrm{ABC}, 06 / 03 / 1985)$

c. - No ha contestado a mi pregunta, ¿qué dice Aznar a esto? (Cambio 16, $\mathrm{n}^{\circ} 975$, 30/07/1990)

(58) a. Si yo contesto a esta entrevista, en vez del alcalde, es porque soy el portavoz del cquipo de Gobierno; (ABC, 29/01/1985)

b. De los 400 opositores que contestan a una prueba de 12 preguntas, el $10 \%$ responde corrcctamente a 3 , el $50 \%$ a 7 , el $30 \%$ a 10 y el resto al total de preguntas de la prueba. (VV.AA, Matemáticas, 1998)

c. Estas interesantes tcorías no contestan a la pregunta de cómo surge la vida, sólo la trasladan a otro lugar, por tanto la incógnita sigue existiendo. (M. Gatcía Ramos, 1987)

\section{9. $\mathrm{N}_{0}$ [humano] le $e_{\mathrm{N} 2}$ contesta a $\mathrm{N}_{1}$ [objeto semiótico] (a $\mathrm{N}_{2}$ [humano])}

El clítico dativo le sitúa la interpretación direccional del oblicuo a caballo entre un locativo y un dativo (59): la marca de transferencia lograda a un receptor (el le dativo) se combina con la especificación de la parte relevante de un producto del mismo receptor. De ahí que el clítico tienda a interpretarse como un dativo posesivo, no actancial, que viene en apoyo del oblicuo, por lo cual este último parece acercarse de la posición actancial dativa, pero sin identificarse totalmente con ella, teniendo en cuenta que la correferencia no es directa, sino que estriba en una relación del tipo parte/todo. Este esquema construccional difumina tanto la categorización semántica léxica como la caracterización de la construcción en su conjunto. La correferencia indirceta y parcial induce un proceso de extensión metonímica: como el oblicuo sólo remite indirectamente al receptor-interlocutor, --perfilando una realización suya - en (59b), por ejemplo, es el programa producido por el pcrsonaje -, se acude al clítico para forzar el paso a una visión global, holística, del receptor-interlocutor, ya que el clítico dativo suele remitir a un referente humano. De ahí que entonces parezca permitida la infercncia de que el mensaje --posiblementc incluido en el predicado verbal- alcance efectivamente el ámbito del interlocutor indirectamente aludido. ${ }^{6} \mathrm{Si}$ en este esquema importara disociar el dativo del oblicuo, habría más casos de duplicación. Pero resulta que (60) es un hápax del habla oral.

6 El que este fenómeno ocurra con mayor facilidad cuando no hay objcto directo expreso, apunta otra vez hacia la necesidad de hacer intervenir otro dominio conceptual que el dc la transferencia. 
(59) a. Alirmó que desde el mes de enero está pidiendo que se aporten esas cintas y quc testifique Navajas, sin que le hayan contestado aún al escrito de solicitud. (ABC, 28/05/1997)

b. - No te preocupes de nada -me dice-, esto es una cstupidez, pero - y se ajusta las gafas mientras parece pensar algo - seria bucno que me consiguieses la cinta del programa de Butano del dia anterior al quc le contestaste tú, es decir, la del 9 de febrero. (J.R. de la Morena, 1995)

c. Nadie me ha contestado todavía a la pregunta de qué diablos estoy haciendo yo en ella. (J. Sierra i Fabra, 1995)

(60) Le contesto a usted a la pregunta en breve, pero Hemos salido del tiempo, si ustedes quicron yo dejaría No te quepa duda que seguiremos (Televisión, Madrid, 24/05/91)

Lo habitual es que el interlocutor vaya designado como participante afectado mediante el clítico solo. En intercambios orales el hablante a veces no se contenta de señalar asi la telicidad del proceso, sino que además marca con adjetivo posesivo la relación metonímica entre los polos iii y iv de la figura 10. Este recurso aparcntemente redundante permite insistir en el carácter delimitado y circunstancial del intercambio: la respuesta se atiene al marco en que encaja la pregunta y sólo reconoce en el interlocutor la figura que cumple la función de interrogar dentro de ese marco. De ahí que vaya asociada con marcas conclusivas $\mathrm{ya}^{7}$ (61a), con eso (61b)).

(61) a. - Me parece que ya le he contestado a su pregunta. (Cambio 16, $\mathrm{n}^{\circ} 954$, $05 / 03 / 1990$ )

b. Entonces, creo que con eso te contesto a tu pregunta. Si guardo más o no guardo más, eso yo también tengo que velar por mis intereses. (TVE 1, 27/10/84)

En la medida que el clítico remite al entrevistador al que también hace eco el posesivo en su/tu pregunta, bien puede tildarse la construcción (61) de fusión entre dos esquemas relacionales, uno direccional-locativo y otro reactivo-dativo.8 El que esta fusión sintácticosemántica se dé sobre todo con contesiar, subraya la importancia del estatuto del interlocutor para el perfil interaccional.

\subsection{Preguntas, llamadas, mensajes contestados vs. preguntas, objeciones, ataques respondidos}

En la conceptualización del evento de RESPUESTA fluctúa el estatuto de los participantes afectados. En la voz activa tanto $\mathrm{p}_{\text {}} i$ (polo IV de la figura 10) como $\mathrm{I}_{\mathrm{t} 2}$ (polo III) aparecen a monudo en posición posverbal focalizada. Pero como su papel antagónico deriva de su previo papel de protagonista, también son susceptibles de ser tematizados. Esto explica su aptitud para acceder al rango de sujeto de la pasiva auxiliada. El orden lineal refleja entonces icónicamente la sucesión en el tiempo. 
Los nombres con los que pregunta alterna como sujeto de la pasiva auxiliada son reveladores de la diferente orientación axiológica de contestar y responder. Contestar viene asociado con nombres como llamada, mensaje, carta, escrito. A menudo el contexto confirma que estos objetos semióticos son tomados en su vertiente tangible de señal acústica (llamó (62a)) o escrita (llegaban (62b)). Su transmisión por un canal apropiado causa un impulso de energía: por defecto, se descuelga el teléfono (62a) y el destinatario a su vez escribe una carta al remitente (62b). El ejemplo (62c) ilustra un tipo de extensión metonímica particular: el sonido que corresponde al cstallido de un arma automática también se concibe como una señal que suscita otra del mismo tipo. El propio contexto explicita, además, la idea de que se trata de un «diálogo», por muy «desatinado» que sea. Para la caracterización de situaciones ritualizadas que se desenvuelven de manera rutinaria se acude a la pasiva pronominal (63).

(62) a. Llamó y su llamada no fue contestada. (J. Jiménez Lozano, El grano de maíz rojo, 1988, (Relatos))

b. El resultado era que asi me llegaban muchas más cartas y, apenas contestada una, recibía otra. (L. Goytisolo, 1984)

c. - Entonces será que la guerra pasada aún no ha terminado -se empccinó el chófer.

Sonó una nueva descarga, esta vcz más cerca, que fue contestada por otra, establcciéndose un desatinado diálogo, una especie de toma y daca de traquidos parecida al dc una burlesca batalla de petardos en Carnaval. (G. Sánchez Espeso, 1985)

(63) a. El Scrior Arzobispo decía siempre la misa, daba él la comunión, y todo se contestaba en gallego (entrevista 1998)

b. En el Senado, se aprobaron 13 proyectos de ley, tuvo lugar la reforma del reglamento y la creación de la comisión general de las Comunidades Autónomas, se contestaron 18 interpelaciones, 85 preguntas orales y 1.171 escritas. (La Vanguardia, 25/01/1994)

El verbo contribuye a precisar el significado que cabe dar al concepto de PREGUNTA. El que una pregunta esté contestada significa que fue tomada como señal apelativa, e implica que se le ha hecho eco, que dio lugar a una toma de posición (64a). La modalidad positiva o negativa de la contestación marca la confirmación o infirmación del supuesto de la pregunta (64b). Con responder, en cambio, la pregunta se concibe como planteamiento requiriendo una elaboración complementaria. Inchuso cuando se responde negativamente (65a), la reacción se ve cargada de significado añadido, y puede trascender el punto de vista del respondiente. Responder no significa que la cuestión estć resuelta o siquiera tratada salisfactoriamente, sino que fue acogida como interrogante, procesada como objeto de reflexión (64b-d). Esto incluso puede manifestarse a través de una nucva pregunta (65e). Resulta pues que se puede responder sin contestar como, al revés, se puede contestar sin responder. Lo cual comprueba la diferencia axiológica entre ambos.

(64) a. Queda contestada ahi la pregunla. (Televisión, 08/04/91, Telemadrid)

b. (...) por lo que la pregunta de Maxwell fue contestada afirmativamente. (Maravall Casesnoves, 1992)

(65) a. -Dime tú por qué has querido que viniéramos al Lady Bird.

Pero esa pregunta no le fue respondida. Lucrecia le dio lentamente la espalda y caminó hacia el teléfono (...) (A. Muñoz Molina, 1987) 
b. Y, finalmente, se suscitó una pregunta que no quedó debidamente respondida. (ABC, 07/05/1985)

c. No será admisible una pregunta cuando en los tres meses anteriores se hubiere presentado y respondido una pregunta igual o similar. (E. García de Enterría, et al., 1996)

d. Surge al final del análisis una serie de preguntas que no han podido scr respondidas del todo con la investigación realizada. (M. T. Bazo, 1990)

e. Habíamos entrado en esa fase de la conversación en que cada pregunta era respondida con otra pregunta. (E. José, 1991)

Con responder se acude más fácilmente a la construcción mediopasiva para evocar un tipo de actividad atribuible a un agente arbitrario o velado, destacando la modalidad (con el asentimiento de... (66a)), la finalidad (a todas estas cuestiones (66b)) o ambas (66c).

(66) a. Todo era palabras de amor. Eran como notas que no se oían, pero se sentían; se recibía su sabor como una palabra y se respondía con el asentimiento del gustar, paladear, desleír hasta el úttimo vestigio del sabor, hasta borrarlo, consumir el último resto, (...) (R. Chacel, 1976)

b. Yo no estuve, pero si hubiera sido uno de cllos, ¿qué hago contra una docena de salvajes? ¿cómo lo impido? Imaginemos que soy policía y voy armado; ¿uso el arma? idisparo al aire? Si se responde a todas estas cuestiones se hubiera salvado probablemente la vida de David. (El Mundo, 11/11/1995)

c. A este respecto cabc mencionar, vaya como ejemplo, que Wason y sus colaboradores (1963) han comprobado la lentitud con que se responde a las cucstiones formuladas en términos negativos, debido probablemente a la profunda tendencia que muestran los sujetos a traducirlas a un lenguaje afirmativo, y asimismo a las connotaciones inhibitorias asociadas con el adverbio «no». (J.L. Pinillos, 1975)

En la pasiva auxiliada de responder, los sujetos que alternan con pregunta no denotan objetos scmióticos, sino que son de índole predicativa. Que tengan una inflexión argumentativa negativa (67), neutra (68), o positiva (69), la respuesta no se da en términos de contraposición sino que es más bien encubridora. Frente a objeciones (67a) o ataques (67b), la respuesta no se vale de la refutación o el contrataque directos, sino que acude a estrategias de amortiguación e incluso amortización. La cautela se manifiesta cn la modalidad epistémica (puede ser respondida (67a)) y la negación (67b).

(67) a. Esta objeción, sin duda importante, puede ser respondida a través de dos estrategias distintas: 1. no hay razones filosóficas o cognoscitivas de peso que hagan suponer que la TI sc va a ver afectada si "Sólo» se logran identidades relativas a cada especic; 2. contamos con un concepto general de dolor, que es el mismo para organismos diferentes. (E. Rabossi, 1995)

b. Los virulentos ataques que comienzan a prodigar los constructores no son respondidos por Mario Conde. El planteamiento del presidente de Banesto sigue siendo que ése es un problema del Banco Central, que por lo tanto tiene que resolver Alfonso Escames. (J. Cacho Cortés, 1988)

Responder ticne un efecto apaciguador, sea cual sea el punto de partida. Aunque en sí nombres como afirmación, cuestión, interrogante, comentario expresan conceptos declarativos más bien neutros, al ir en plural pueden acumular una fuerza que no se contrarresta 
mediante una simple reacción (contestar) sino que requiere un poder de recupcración (68a), neutralización (68b), resorción (68c) o amplificación (68d) a la altura de los desafíos planteados. La elaboración de la parte posverbal de la construcción subraya la efectividad de la respuesta.

(68) a. Estas afirmaciones fueron respondidas por Castro, quien aludió a la sinvergonzonería política a la que han llegado algunos dirigentes socialistas, al afirmar que el PP no ha puesto objeciones en el sistema de contratación (ABC, 20/11/1997)

b. En todo caso, la letanía de cuestiones era respondida con un Nunca lo harán que prohibía todo acercamicnto, toda interferencia, toda aparición. (J.M. Merino, 1987)

c. Estos interrogantes han sido respondidos con bastante precisión por los distintos análisis formulados sobre el tema y que hemos reducido a cuatro, advirtiendo que sus límites no son precisos y que con frecuencia se entremezclan entre sí. (N. Seseña, 1997)

d. Existen locales de estas características que han ido constituyéndose un público habitual quc ocupa las primeras filas y termina por formar parte del espectáculo. Son los que responden a las pullas o a las incitaciones que las vedettes les dirigen desde el escenario, los que -sabićndose casi de memoria el espectáculo- esperan con impaciencia el momento que más les complace o lo preparan con un comentario en voz alta que, a veces, es respondido tambićn por la artista; se establece así un insólito toma y daca entre la platea y el escenario que forma parte del encanto del music-hall y que es muy dificil hallar en otro tipo de actuación. (E.L., Gete-Alonso, 1987)

Finalmente, nombres como expectación (69a), exigencia (69b), desafio (69c), Jexibilidad $(69 \mathrm{c})$ ) son portadores de una perspectiva alentadora. La valoración del paso de la virtualidad a la realización suele marcarse a nivcl del núcleo verbal (está siendo (69a, 69d), deben $(69 \mathrm{~b})$, puede $(69 \mathrm{c})$ ). Si en vez de responder se hubiera utilizado contestar, no se habría obtenido una imagen de convergencia, sino de divergencia.

(69) a. La gran expectación que había despertado John Ngugi está siendo respondida por el propio atleta que en es estos momentos manda en solitario la prueba, (..) (TVE, 2, Domingo Deporte, 02/04/89)

b. Al concluir esta sucinta revisión de las más importantes tesis etiopatogénicas acerca de la esquizofrenia, sentaré mi punto de vista acerca de qué cxigencias deben ser respondidas por cualquiera que sostenga una tesis determinada. (C. Castilla del Pino, 1980)

c. Que profeticemos las dificultades como un hecho externo que se trata de conjurar y no un desafio que puede ser asumido y respondido. Fundamentalmente se va a plantear un proceso de adaptación al cambio y todo va a depender de la capacidad y la voluntad colectiva de aceptar sus consecuencias. (F. Fernández Ordóniez, 1980)

d. La flexibilidad de la que hace gala el Gobierno está siendo respondida por los nacionalistas vascos con su voluntad de no ser maximalistas respecto a los Presupuestos Generales del Estado para 1998. (ABC, 10/10/1997)

\subsection{Palabras, medidas, prácticas, figuras públicas contestadas}

La construcción pasiva refuerza la dimensión dicotómica de la relación establecida por contestar. De ahí probablemente que no haya ocurrencias con saludo como sujeto de la pa- 
siva: en vez de un puente tendido surgiría la imagen de una práctica de esgrima. La pasiva destaca la fuerza y el protagonismo del contra-agente, especialmentc con la preposición por (cf. Delbecque 2003). Es típico que la reacción «contestataria» se perfile mediante adverbios de intensidad (muy (70a, 72b, 73a), más duramente (70b)), sc impute a destacados actores sociales (la propia oposición (71a), el PSOE (71b), un sector de la Iglesia hispana (72a)), y se subraye la dimensión extensional (tanto por unos como por otros (70a), numerosos médicos (71a), por tirios y troyanos (74)), o se insista en su carácter justificado (puesto que (72b)) o cxitoso (con éxito (70b)). En la entidad tematizada se plasman los distintos aspectos del ejercicio del poder: puede ser performativo —decisión judicial (veredicto (70a)) o gubernamental (medida (70b)) -, prospectivo (modelo propuesto (71a), plan (7lb)) o denotar una práctica ritualizada (liturgia (72a), uso (72a)). Además de partir del polo IV (figura 10), también se puede tomar como punto de partida el polo III, con tal que se aborde bajo el aspecto de un rol social particular (gran comunicador (73a), portavoz (73b), ministro (74a)). Más que en la construcción activa, el blanco de la reacción se encuentra aislado, arrinconado. Es revelador al respecto la relación adversativa entre contestados pero también escuchados (73a), así como el uso de la forma participial como atributo (el más contestado de los ministros (74a)) e incluso como epíteto (el contestado A.V.Q. (74b)).

(70) a. No obstante, el veredicto fue muy contestado tanto por unos como por otros. $(\mathrm{ABC}, 26 / 04 / 1988)$

b. Fue ésta la medida más duramente contestada por los distribuidores, que recurrieron con éxito ante el Tribunal Supremo C. Torreiro, 1995)

(71) a. «Es incrcíble cl modelo de Sanidad mixta que propone y que está siendo contestado desdc la propia oposición y por numerosos médicos. (...)» $(\Lambda \mathrm{BC}, 12 / 05 / 1988)$ b. - El Plan Extraordinario de Inversiones ha sido contestado por el PSOE en el último pleno. (Canarias 7, 02/02/2001)

(72) a. Los monjes franceses, que acudieron a España en número considerable, trajeron con ellos la liturgia romana, contestada por un sector de la Iglesia hispana, y ocuparon algunas sedes importantes, como las de Toledo, Osma o Sigüenza. (F. Calvo Serraller, 1997)

b. EI uso del nivel urinario de MHFG como indicador de la actividad noradrenérgica cerebral ha sido muy contestado, puesto que experimenta grandes variaciones bajo el influjo de ciertos factores externos (F. Alonso-Fernández, 1988)

(73) a. Tenía el morbo de esos grandes comunicadores como Encarna Sánchez o el «Butano', que luego son muy contestados pero también escuchados. (L Díaz, 1992)

b. El portavoz socialista, que también dijo que a la Fiscalía General del Estado no se podía ir a hacer apostolado y sacó a relucir las presuntas amenazas de Miguel Ángel Rodríguez al presidente dcl grupo Zeta, fue contestado por Álvarez-Cascos, quien replicó en defensa de Cardenal que el desprecio a las creencias de los demás demostraba el findamentalismo del diputado que había hecho la pregunta. (ABC, 22/05/1997)

(74) a. En definitiva, Carlos Solchaga, sin duda uno de los más preparados ministros del Gabinete, es también seguramente el más contestado por tirios y troyanos. (ABC, 12/07/1989) 
b. El presidente del PP de Cataluña, el contestado Aleix Vidal Quadras, manifestó ayer su cuforia: «Cataluña ha dejado de ser pujolista». (El Mundo, 20/11/1995)

Compárense los ejemplos anteriores con el efecto sintonizador del uso esporádico de responder en voz pasiva con sujeto humano (75).

(75) Hablamos con voz queda, para no desentonar en el ambiente, y fuimos respondidos con frases de agradecimiento. (J. Martinez Reverte, 1979)

\subsection{2. $\mathrm{N}_{0}$ [+humano] responde a $\mathrm{N}_{1}$ [contenido proposicional en preganta, llamada, men- saje]}

Cuando responder se asocia con llamada, mensaje, carta, escrito, estos objetos semióticos no se construyen como régimen directo sino como oblicuo. Con responder, la construcción sin otros participantes que el sujeto y el oblicuo es más frecuente que con contestar. Tambićn es mayor la variedad de nombres que alternan en ambas posiciones (5.12-16). Tras los papeles agentivos de $\mathrm{N}_{0}$ y $\mathrm{N}_{1}$ interesa la complementariedad de los contenidos que aportun. Más que de cumplir la formalidad de devolverle al interlocutor el tipo de signo impuesto por el marco en que se formuló la pregunta, se trata, con responder, de ocuparse de verdad del asunto. A diferencia de contestar, se hace hincapié en la necesidad de abordar un tema de forma adecuada, es decir, como lo requiere el tema (76a), más allá de un determinado marco dialogal (76b) o institucional (76c).

(76) a. - -..Esos, amigo -prosiguió el rabí captando mis dudas-, serán los grandes estafados y, en consecuencia, los últimos en el Reino de mi Padre.

-Entonces, tu Dios es un Dios de amor...

Jesús pareció enojarse.

-_Tú eres Dios!

- ¿Yo, Señor?...

- En verdad te digo que todos los nacidos llevan el sello de la Divinidad.

-Pero, no has respondido a mi pregunta. ¿Es Dios un Dios de atnor? (J.J. Benítez, 1984)

b. Pero prefiero presentaros mi punto de vista a través de un pasaje de mi vida, porque estoy persuadido de que asi respondo mejor a la pregunta. (Bernardo Atxaga, Sobre el Tiempo [Cuentos de Fútbol] 1995)

c. ¿Hablar de literatura femenina es un reclamo feminista? ¿Por qué no se hablā de literatura masculina? ¿Por qué los grandes personajes femeninos de la literatura universal (Emma Bovary, Ana Karenina, Ana Ozores...) han sido creadas por hombres $y$, en cambio, no existe un prototipo de personaje masculino al que haya dado vida una mujer? Cuatro escritoras, que esta semana han participado en El Escorial en un curso sobre narrativa femenina, responden a estas preguntas. (ABC, 08/09/1997)

De ahí que este esquema construccional oblicuo sólo fusione raramente con el esquema dativo (5.13), contrariamente a lo que ocurre con contestar (cf. 5.9). Cuando ocurre, el polo IV - el oblicuo en posición inicial - se vincula al polo III -expresado bajo forma clíticay se refuerza la focalización de la propia respuesta (polo II) en posición posverbal (77). 
(77) a. A la primera parte de la pregunta te respondo en el sentido de que las penas vienen establecidas en el Código Penal. (Conversación, 1992)

b. En el brindis final, Tierno recordó las palabras de Natalio Rivas cuando, dírigiéndose a una audiencia similar, justo después de saberse vencedor de unas elecciones, preguntó a sus seguidores: «Bueno, ahora que hemos ganado, ¿qué queréis?» $A$ lo que le respondieron todos: «jLos cargos, don Natalio, los cargos!» (ABC, 11/10/1982)

\subsection{3. $\mathrm{N}_{0}$ [-humano] $l e_{\mathrm{N} 1}$ responde}

En cambio, cuando sólo se da el clítico (polo III), sin referencia anafórica al polo IV, se vuelve más estrecha la relación entablada cntre los interlocutores (polo III - polo I). El terreno ya vicne preparado en el contexto anterior para situar la convergencia a nivel de las personas (yo no le fallarta (78a), pasaron varios dias (78b)).

(78) a. Escribió a don Fermín y no obluvo respuesta; repitió la tentativa con el mismo resultado; y al fin, considerando, acaso por el tono más sereno y universitario de mi ensayo, que yo no le fallaría, me escribió a mí. Le respondi, en efecto, y ćl replicó con una carta estupenda, orsianisima, acerca del ejemplar recibido y de las generaciones literarias de nuestro siglo XX, que por desgracia se me ha extraviado. (P. Laín Entralgo, 1976)

b. Asi pasaron varios días, hasta el primero en que hizo una observación o una pregunta, no lo recucrdo bien, a la miss. Ella lo miró extrañada, pero le respondió, y él hizo en su cuaderno una nueva anotación. (G.Torrente Ballester, 1988)

\subsection{4. $\mathrm{N}_{0}$ [humano] responde $\mathrm{N}_{1}$ [contenido proposicional] a $\mathrm{N}_{2}$ [contenido proposicional (vago)]}

Si bien responder se usa tras una enunciación, al igual que contestar, la diferencia es que toma como punto de partida el contenido proposicional de la movida anterior. Si interesara la conexión entre la acción instigadora y su agente, habría duplicación clítica (79). Ahora bien, el interlocutor importa más en cuanto conceptor que en cuanto actor, o sea, no interesa por la movida que ejecuta sino por el contenido proposicional que vehicula (argumento del objetante (79a) u opositor (79b)). Como lo ilustra el uso del pronombre personal o relativo neutro sin clítico duplicador, no es el interlocutor como tal, ni su enunciación, sino el planteamiento que requiere una reacción (80). Por extensión, ni siquiera deber haber acto de habla o enunciado anterior para que sea motivada la reacción. Ésta tampoco se traduce necesariamente por palabras. Metafóricamente también se puede atribuir una representación mental proposicional abstracta a eventos no lingüísticas. Acciones, procesos, estados de cosa también pueden motivar un tipo de reacción que justifique el uso de responder. En tales casos desaparece totalmente la posibilidad de insertar un clítico dativo (80-81).

(79) a. Súbitamente me vino a las mientes el recucrdo de esas páginas, y respondí a mi objetante estas o parecidas palabras: (...) (P. Laín Entralgo, 1976)

b. Rato y Arenas responden a Cuevas que el Presupuesto para 1998 favorece la competitividad de las empresas (ABC, , 10/10/1997) 
(80) a. «(...) Se me dirá que, a pesar de esto, supimos dar cima a nuestros gloriosos ocho siglos de Reconquista. Y a ello respondo ingenuamente que yo no entiendo cómo se puede llamar reconquista a una cosa que duró ocho siglos.) (Julián Marías, 1985, cita de Ortega y Gasset)

b. Al terminar se le acercó una periodista, que trabajaba para Ffe en Washington, y le dijo: Habla usted muy bien español, a lo que José María Maravall respondió: Es que soy español. ¿Ah, sí? Sí, soy el ministro (...) (J. Feo, Aquellos años, 1993)

(81) En las máquinas veian los trabajadores una amenaza directa contra su nuevo modo dc vida y respondieron a ello con movimientos desorganizados y espontáneos, pero de gran violencia en algunos casos que conocemos con el nombre de ludismo. ( $S$. Dormido Bencomo, 1990)

\subsection{5. $\mathrm{N}_{0}$ [organismo] responde a $\mathrm{N}_{1}$ [desafio, estrategia, expectativa, necesidad, requisito, rerapia]}

Esta diferencia con contestar es aún más marcada cuando en posición oblicua se encuentran nombres como acusación, amenaza, desafio, estrategia, expectativa, requisito, solicitud, terapia. Más allá de reacciones verbales a algún contenido proposicional (82), responder se aplica de manera general a reacciones argánicas ante influcncias de variada índole. Se trata de una causalidad que no sólo afecta a formaciones humanas (el PDS (83a), el Gobiemo (83b), la Comisión (83c)), sino que se extiende a organismos vivos (linfomas (84a), criterins ecológicos (84b)), parámetros organizativos (84c) y etiologías totalmente abstractas (85). Sea cual sea la reactividad inducida, responder la presenta como un fenómeno de validación del factor causal.

Dos conceptos rigen este proceso de extensión por vía analógica: secuencialidad y adecuación. Como en el caso de la sccuencia pregunta-respuesta, responder señala que un evento sigue en reacción a otro, o sea, que la extensión estriba cn el mismo esquema secuencial acción-reacción: el segundo miembro del binomio se sitúa en la posierioridad del primero, y al igual que lo hace una pregunta, la naturaleza del primer evento tequiere una respuesia. Una respuesta prototípica debe satisfacer un deseo de información, debe ser adecuada. O sea, que tiene que corresponder al hueco dejado por la pregunta y amoldarse a él. Ahora bien, la noción de adecuación también se encuentra en otros dominios, de modo que la conceptualización global puede deslizarse del área de la transferencia a la de la adecuación funcional. De ahí que encontremos responder en contextos donde alterna con verbos como corresponder, adaptarse, ajustarse, conformarse, convenir, cumplir, satisfacer, servir. Por generalización, la respuesta ya no supone ninguna agentividad anterior. Se entiende en términos de conformidad aun cuando del primer miembro del binomio acción-reacción no emana ningún estímulo ni incentivo indirecto. Esto abre el paso a relaciones de correspondencia que ya no requieren ninguna agentividad de parte del respondiente tampoco, que sea humano o no (5.16).

(82) a. Ahora vamos a ver qué pasa con Karembeu, porquc en caso de no responder a las expectativas, toda esta polémica no habrá servido para nada. (Cadena SER, $07 / 11 / 96)$

b. Las declaraciones de Durán responden a las acusaciones públicas de Juan Figucroa a varios medios, en las que aseguraba que Gustavo Duran intentó comprar a Nicolás 
Piñeiro antes de repelir la operación con el diputado de IU, Miguel Angel Olmos. $(\mathrm{ABC}, 24 / 05 / 1989)$

c. El proyecto que prevé aprobar el Consejo de Administración de la compañía la próxima semana sólo responde a la necesidad de afrontar la modernización de la flota. (ABC, 25/09/1997)

(83) a. El PDS, la formación mayoritaria de El Olivo, ha respondido así al desafío de Bertinotti, que estaba pidiendo al Gobicrno en materia de pensiones algo a lo que los mismísimos sindicatos habían decidido renunciar. ( $\Lambda \mathrm{BC}, 10 / 10 / 1997)$

b. El Gobiemo daria loables muestras de prudencia si al final de este nuevo debate que se va a plantear acalla los conflictos desatados o en ciernes con la configuración de un átea que cambie el aislacionismo religioso por un amplio horizonte de formación espiritual. Así habría respondido también, en buena medida, a la acusación de descuido de la educación de los aspectos más profundos del hombre, todavía en pie. (ABC, 18/04/1989)

c. (...) bien porque la Comisión no haya respondido positivamente a anteriores solicitudes, formuladas por la comisión competente o contenidas en resolucioncs aprobadas por el Parlamento por mayoría simple. (E. García de Enterría, et al., 1996)

(84) a. Hay linfomas que responden a las terapias y otros que no. ( $\mathrm{ABC}, 05 / 04 / 1996)$

b Análisis del ciclo de vida: los criterios ecológicos responden a requisitos que emanan del análisis del ciclo de vida del producto, incluyendo la fabricación, distribución, utilización y eliminación del mismo. (Páginas WEB, 1999)

c. La pluralidad de funciones y actividades que lleva a cabo el CNICD pueden agruparse en tres áreas fundamentales de actuación que responden a una estrategia permanente de dar apoyo científico al deporte y de mejorar cualitativamente su práctica. (Páginas WEB, 1999)

(85) a. La dirección del centro sanitario Princesa de España, en Jaén, anunció ayer el fallecimiento de dos personas que habían ingresado pocas horas antes en el hospital a causa de síntomas que responden al llamado "golpe de calor». (La Vanguardia, 30/07/1995)

b. La cvidencia empírica disponible y los resultados de las abundantes investigaciones sobre cómo tienen lugar los procesos de cambio en los sistemas escolares (Reynolds et al, 1997) han puesto de manifiesto que dichos procesos no son homogéneos ni responden a nexos causales de carácter lineal. (Páginas WEB, 1999)

Con responder, el acto de descolgar el teléfono, o de abrir la puerta, no sólo se ve como la reacción al sonido del teléfono o el toque del timbrc - como es el caso con contestar (cf. (32b), (62a)) sino que remite a la convergencia entre la intencionalidad de la reacción y el deseo de entrar en comunicación. El proceso metonímico (el sonido remitiendo indirectamente a la voz humana) se dobla de un proceso metafórico, ya que tiene la fuerza de apelar la validación de $\mathrm{N}_{1}$ por $\mathrm{N}_{0}$ como algo necesario (86). Que la validación sea completa (asi (83a)) o parcial (en buena medida (83b)), el contexto a menudo corrobora su carácter apremiante (ceñirse a las reglas... transgresión de las normas (87a), asumido... cumplir esta tarea obligada (87b)).

(86) « (...) ¿Y si no hubiera respondido al tclófono un martes? ¿Y si no hubiera aceptado el trabajo aquel lunes?) (J. Marías, 1992) 
(87) a. En el cine clásico, la habilidad y originalidad del director consistía en ceñirse a las reglas, para responder a las expectativas del público, pero sin renunciar a realizar una obra dotada de interés y de estilo personal. Más adelante, la transgrcsión de las normas comúnmente aceptadas como canónicas de cada género o la eliminación de las barreras entre unos y otros (El jovencito Frankenstein, 1974), se convirtieron en distintivas del cine moderno. (Francisco J. de la Plaza \& $\mathrm{M}^{a}$ José Redondo, 1993) b. En España aún no hemos asumido y respondido a las tres grandes interpretaciones que en este siglo se han hecho dcl Santo, tan geniales como problemáticas: Baruzi, Morel, Balthasar.. El centenario nos debería impulsar a cumplir esa tarea obligada. (ABC, 13/12/1991)

\subsection{6. $\mathrm{N}_{\mathrm{a}}$ [instancia] responde a $\mathrm{N}_{1}$ [tipo]}

De manera general, el esquema binómico integra información relativa a un esquema de correspondencia de orden superior. En un nivel más abstracto, los actos que sirven de (respuesta) comparten una base con el acto previo, primero, sca por pertenecer a la misma categoría de signos socio-perceptuales, sea por completarse uno a otro en términos de información, sea por reflejar ambos el mismo tipo de intención (buena o mala), de parte del agente. Mientras que el esquema anterior-posterior rige secuencias de eventos, el esquema de correspondencia incorpora tanto relaciones estáticas como dinámicas. No es necesario que el primer elemento preceda al segundo en el tiempo. La relajación del requisito del orden temporal explica buena parte de las diferencias con contestar. Sólo responder llega a significar simplemente «corresponder», «ser similar», «parecerse en número, tamaño, posición, carácter, etc.», «adecuarse», «ser del tipo, de la clase, del género de». A la noción de precedencia temporal se le sustituye el concepto de precedencia simbólica.

La noción de similitud determina la vía de extensión metafórica. Permite pasar de una estructura eventiva causativa (alguien/algo responde algo a alguien/algo) a una estructura atributiva, no causativa (alguien/algo responde a algo). Según la amplitud y el grado de especificidad de la categorización expresada por la entidad oblicua, la relación podrá entenderse en tórminos de tipología (perfil (88a), esquema (88b)), conformidad (realidad (88c), condicionamientos (89a)), inclusión (la estética de hoy (89b)), cumplimiento (intención $(89 \mathrm{c}))$.

(88) a. Su agresor responde al perfil establecido en la estadística, un hombre desconocido y de apariencia normal que se demostraba a si mismo su virilidad con palabras soeces y la utilización de una violencia desmedida. (TVE 1,29/08/92)

b. No es difícil averiguar qué personajes de la actualidad responden a este esquema de juego. (ABC, 27/11/1987)

c. Cortemos este flujo inicial de $\Lambda$ viraneta ensalzando a su padrc, de forma tan rotunda e hiperbólica que, con toda seguridad, no responde a la realidad y que culmina con la supuesta estima del todopoderoso Godoy, como también amistades importantes en la Corte, igualmente dudosas. (P. Ortiz-Armengol, 1994)

(89) a. Estas obras responden a condicionamientos muy diferenciados, que, en el caso de Salamanca, contribuyen a que su lenguaje -un lenguaje versátil ya de por sí- se haya abierto simultáneamente a sugestiones diversas. (ABC, 07/06/1996)

b. «Ni la poesia social ni el neoculturalismo responden a la estética de hoy» (ABC, 30/04/1982) 
c. Lo que consigue con la unidad temática del libro y la sólida cohesión de sus partes, que responden a una intención del poeta —advertible incluso en aspectos mćtricos y formales-innovadora en su trayectoria poćtica. (ABC, 22/11/1991)

d. Este síntoma responde a la reducción de las fosas nasales o de la rinofaringe, dificultando el paso del aire. (Efímero, 1998)

\subsection{7. $\mathrm{N}_{0}$ [humano / institucional] responde de (par) $\mathrm{N}_{1}$}

Por último, cxiste un esquema oblicuo que hace abstracción de los polos II, III y IV. Perfila un $\mathrm{N}_{0}$ [humano] que responde al perfil $\longrightarrow \mathrm{o}$ sea, posee los atributos necesarios (cf. 5.16) - para responder a toda posible acción (IV) de cualquier interlocutor (III) de una manera que sea apropiada a la situación (II) (cf. 5.1). En vez de mostrar un $\mathrm{N}_{0}$ en actividad, se hace hincapié en su potencialidad agentiva. Conforme al significado de responder, su responsabilidad puede interpretarse desde dos puntos de vista: el de $\mathrm{N}_{0}$ y el de los interlocutores susceptibles de llevar a $\mathrm{N}_{0}$ a responder. En el primer caso, el propio $\mathrm{N}_{0}$ presenta la disposición y capacidad suficientes para asumir sus compromisos y hacerse plenamente cargo de $\mathrm{N}_{1}$, relativo a su dominio personal (90). Como el tipo de agentividad es, en principio, correlativo al dominio de $N_{0}$ (e.g., carniceros... carne (91a)), por defecto, $N_{0}$ no rebasa los límites de su dominio (92a-b). Al insertar un dativo, cl hablante señala que $\mathrm{N}_{0}$ también le reconoce un dominio propio al interlocutor ( $92 \mathrm{c}$ : el alcalde frente al jefe de la guardia civil). Uno también puede extender su control más allá de la cuenta (93a) o echarlo a perder y volverse irresponsable (93b-c).

(90) a. Tengo 76 años y respondo de mis acciones. (La Vanguardia, 15/09/1994)

b. Yo creo que la crisis, en gran parte, está superada. Y respondo de lo que depende de uno, pero no de otras personas y de las relaciones entre ellas, sobre lo que no puedo opinar. (Tiempo, 10/12/1990)

c. Proponemos gobiernos responsables, que dan la cara, que responden de sus compromisos. (El Socialista, $\mathrm{n}^{\circ} 651,04 / 2003$ )

(91) a. Manuel Becerra dijo que «los carniceros respondemos de la carne» y explicó que trescientos profesionales reunidos el sábado constataron la recuperación de ventas al $80 \%$. (La Voz de Galicia, 18/12/2000)

b. La Expo es el evento más destacado y más complejo de la cclcbración del Quinto Centenario, que tiene sus organismos espccíficos, Comisariado y Sociedad Estatal, que responden de su funcionamiento. (Tiempo, 10/12/1990)

c. Los garajes responden plenamente de los daños que puedan sufrir los vehículos que guardan, incluido el robo, según ha manifestado el presidente de la Asociación de Empresarios del Ramo, Jacinto Barrio. (ABC, 25/01/1985)

(92) a. No respondo de lo que pueda pasar. (M. Salisachs, 1975)

b. Yo no respondo de que Ud., hombre activo y de este siglo, si sc propusiera fumar en pipa de arcilla, no quebrase dos o tres todos los días. Tendría que comprarlas por docenas, llevar sus bolsillos atiborrados de pipas; eso es desagradable. (J. Verdaguer, 1980)

c. «Si usted sc aviene a no detener a nadie, yo le respondo de que en menos de una hora quedará totalmente evacuado el edificio». (P. Laín Entralgo, 1975) 
(93) a. "Ya sabemos que no corresponde a Pujol responder de lo que pasa en España, aunque muchas veces sí se preocupa, pero si apoya al Gobiemo debe ser porque tiene muy buenas razones), concluyó Eguiagaray. (El País, 16/01/1998)

b. Cuando me enamoro, no respondo de mí. (Tiempo, 29/01/1990)

c. Por mi madrc abrc o no respondo de mis sentimientos... (M. Martínez Mediero, 1988)

En el segundo caso, la responsabilidad de $\mathrm{N}_{0}$ se cjerce bajo control externo. Se le ve más bien como responsabilizado que como responsable. Esta modalidad predomina cuando están en juego intereses superiores que pueden resultar pcrjudicados por mala gestión, fraude o estafa de parte de $\mathrm{N}_{0}$ (empresas públicas (94a), los muebles no eran suyos (94b)). La normatividad se expresa mediante auxiliares deónticos (deber (94a, 95a, 96b)). La instancia controladora suele mencionarse en forma de adjunto introducido por la preposición ante (ante los británicos (95a), ante la comisión constitucional (95b), ante un tribunal (96a). Cuando se han cometido crímenes contra la humanicad, no hace falta explicitar que es ante todos que $\mathrm{N}_{0}$ debe rendir cuentas (96b).

(94) a. Finalmente, cada uno debe responder de sus actos. La impunidad no es aceptable. Los franceses tienen en la memoria demasiados cscándalos financieros, especialmente en algunas empresas puiblicas. (El País, 08/05/1997)

b. Los responsables deben explicarlas ante el Parlamento. Y responder de ciertas iniciativas -grandes comisiones a empresas encargadas de captar participantes, rcserva desmesurada de plazas de hotel pagando por adelantado- que, si no ilegales, sí resultan extravagantes: como la de quien se entretiene tirando la casa por la ventana. Con la particularidad de que on cl caso de la Expo los muebles no eran suyos. (El País, 01/11/1997)

(95) a. Los cargos públicos deben responder de sus acciones y dccisiones ante los británicos y han de someterse al escrutinio público de su trabajo. (Cambio $16, \mathrm{n}^{\circ} 1227$, 29/05/1995)

b. El presidente, que tendrá rango de subsecretario, responderá de su geslión ante la comisión constitucional de la cámara baja. (Diario de Arousa, 17/11/2002)

(96) a. El ex ministro Alain Carignon compareció ayer ante un tribunal $\cdot$ de Lyon para responder de los cargos de corrupción política mientras era alcalde de la ciudad de Grenoble. (La Vanguardia, 16/05/1995)

b. Los veinte hombres deben responder de la matanza de 13 personas on 1987, entre ellas seis niños, en la ciudad negra de KwaMakhuta, al sur de Durban. (La Vanguardia, 02/12/1995)

La preposición de indica que $\mathrm{N}_{1}$ forma parte o ha llegado - debida o indebidamente - a formar parte del dominio de $\mathrm{N}_{0}$. Si en vez de una vinculación partitiva incuestionable entre $\mathrm{N}_{0}$ y $\mathrm{N}_{1}$, se prefiere expresar una visión discontinua en que $\mathrm{N}_{1}$ destaca como factor condicionante, se acude a la preposición por (cf. Delbecque 1996). Mientras que de presenta la responsabilidad de $\mathrm{N}_{0}$ en términos de continuidad, como algo lógico, natural e incuestionable, por realza y particulariza la relación que se establece entre $\mathrm{N}_{1}$ y $\mathrm{N}_{0}$. Especialmente cuando $N_{1}$ designa personas (97), por permite instaurar la responsabilidad de $N_{0}$ en el acto. Ante el alcance de crímenes y catástrofes permite rearticular o debatir la responsabilidad 
cn términos éticos (es importante... según las normas (97a), debe.. por su responsabilidad (97b), estamos obligados a compartir la responsabilidad (98)). La diferencia entre por y de se manifiesta claramente en enunciados donde coocurren (100).

(97) a. - ¿A dónde va? Identifiquese.

Al tío Antonio jamás le habían hablado en ese tono como no fuera su hermano mayor. Sc quedó estupefacto, sin saber qué responder. Entonces alguien le tomó el brazo, diciendo:

- Yo respondo por él. Es persona de orden.

El que habia hablado lo arrastró hasta el final de los soportales y le dijo en voz baja y nerviosa:

- ¡Váyase, don Antonio. Y no salga de Viladouro! (J. Alfaya, El traidor melancólico, 1991 (relato))

b. - Fingiremos venir de una juerga. Si el portero hace preguntas, yo responderé por todos. (E. Mendoza, 1975)

(98) a. El candidato a ministro de Justicia serbio, Vladan Batic, declaró hoy que «se acerca el momento de juicio» contra Milosevic, e indicó que «es importante que responda por delitos seguin las normas del derecho internacional pero también por los que cometió contra las leyes de Serbia y Yugoslavian. (El Norte de Castilla, 12/01/2001) b. En todo caso, [cl juez Garzón] afirmó que Pinochet debe responder por su responsabilidad en los crímenes cometidos durante la dictadura. (Diario de Navarra, 29/01/2001)

(99) El alcalde de la ciudad, Rudolf Giuliani, confesó que «todos debemos compartir la responsabilidadn por la muerte de Elisa. Una declaración noble que debería llevarse a la práctica. El alcalde, al igual que los directores de los organismos de asistencia social, piensa en términos del sistema, pero no en personas concretas; por lo tanto, todos nosotros, como formamos parte del sistema, estamos obligados a compartir la responsabilidad. El problema es que cuando la culpa se reparte entre muchos a nadic le toca responder por lo ocurrido. (EI Mundo, 03/12/1995)

(100)El ex jugador del Juventus, más que por las palabras de sus compañeros, tenía que responder de su ccgucra goleadora. «Lo importante no es que yo marque goles», dijo, «sino que el equipo gane». (El País, 20/09/1997)

\section{SÍNTESIS}

Partiendo del supuesto de que cada entorno en que se presenta un lexema puede contribuir a precisar su significado, se han inventariado las combinaciones léxicas y configuraciones sintácticas preferentes de contestar y responder, relacionándolas sistemáticamente con el espacio discursivo cuatripolar introducido en el apartado 4. Sin la distinción entre las posiciones II y IV no habría sido posible diferenciar entre los esquemas construccionales comentados en 5.2 y 5.4-5. Sin la distinción cntre las posiciones III y IV no habría sido posible diferenciar entre los esquemas 5.6-7 y 5.8-9, y tampoco se habría podido aislar la combinación I-III-IV (5.9) del esquema triargumental clásico I-II-III (5.1), de la que sólo pueden derivarse directamente el esquema biargumental directo I-II (5.2), el monoargumental I (5.3) y biargumental indirecto I-III (5.6-7). 
La recurrencia de los mismos lexemas hace aparecer relaciones de parecido familiar entre las construcciones (5.1-11). La variación en el número y tipo de participantes así como en su expresión morfosintáctica explica la densidad de la red semántica de contestar (Figura 4). La ambivalencia del perfil de los participantes III y IV en su relación con I (5.4-9) se traduce por cierta indeterminación en cuanto a su papel semántico. Las alternancias construccionales -5.5 vs $5.4,5.7$ vs $5.6,5.9$ bd 5.8 - modulan los papeles semánticos con efectos de distancia y fragmentación que vuelven borrosos los límites entre dativo y acusativo, por un lado, y dativo y oblicuo, por otro. Según que el antagonista sc perfile como dativo o no, la interacción será percibida como poco o muy polarizada. La obtención de una clara lectura polémica, sin embargo, también depende crucialmente del estatuto de los participantes, la (a)simetría entre ellos y el frame en que encajan sus respectivos roles sociales. La importancia de la semántica léxica se revela plenamente en las construcciones pasivas, donde la orientación contestataria viene determinada en gran medida por la categoría semántica de la entidad sujeto (5.11 vs 5.10).

A diferencia de contestar, responder admite la combinación de los polos I, II y IV (5.14). De manera general, sin embargo, su modulación se realiza menos por alternancias construccionales. La variación léxica en las posiciones argumentales de la estructura predominante --N0 responde a N1(oblicuo) - produce modulaciones relacionales que se extienden de la acción máximamente agentiva (5.12) a la categorización abstracta (5.16) pasando por rcacciones metonímica o metafóricamente orgánicas (5.15). Tanto en el constructo sin oblicuo (5.3), todavía cercano al prototipo (5.1), como en el más alejado del prototipo — con oblicuo introducido por de o por (5.17) - se comprueba que la respuesta humana (polo I) se entiende en términos de responsabilidad.

El ensanchamiento de la noción de RESPUESTA manifestado por la variación léxica en torno al verbo responder revela una gran flexibilidad en el manejo de varios de los conceptos constitutivos del dominio de la dinámica de fuerzas (cᄃ. 3.4). La combinación de los conceptos de (i) secuencia dual, (ii) reacción, (iii) correspondencia y (iv) efectividad produce un esquema organizador complejo que podemos denominar «secuencia reactiva de correspondencia efectiva). El significado de responder estriba en el binomio compuesto por un antecedente y un postcedente. Cuando sc denota una reacción verbal, ésta se sitúa en la inmediata posterioridad de otro acto que aparece como la causa - directa o indirecta- de la respuesta. En los usos extendidos de responder la dimensión temporal puede quedar sin perfilar e incluso ser ausente. Entonces la noción de precedencia es interpretada de manera abstracta. A este binomio ordenado, se añade un segundo csquema organizador para explicar que los actos subsecuentes o postcedentes se realizan en reacción a lo que les precede (sea temporal sea nocionalmente). No se trata de una reacción cualquiera, sino que se ajusta a las condiciones y el perfil impuestos por el antecedente, o sea, que se apoya también en un esquema de correspondencia. Se trata, además, de una correspondencia efectiva: la invcrsión de la dircccionalidad resulta en una iniciativa que hace más que reciprocar el impulso recibido (cf. las extensiones e, m, p y q en la red semántica (Figura 3)).

De la variación construccional y las combinatorias encontradas se desprende que más allá de la base conceptual que responder y contestar comparten, el nivel relacional que recibe la mayor prominencia no es el mismo. Responder centra la alención en la relación entre $Y$ y X, y maximiza la capacidad agentiva de $Y$ para generar la respuesta adecuada ante $X$, de tal modo que la entidad $X$ puede ser relegada a un segundo plano. En la figura 11 el espacio operativo de responder se realza mediante el rectángulo horizontal y la flecha en negrita. 


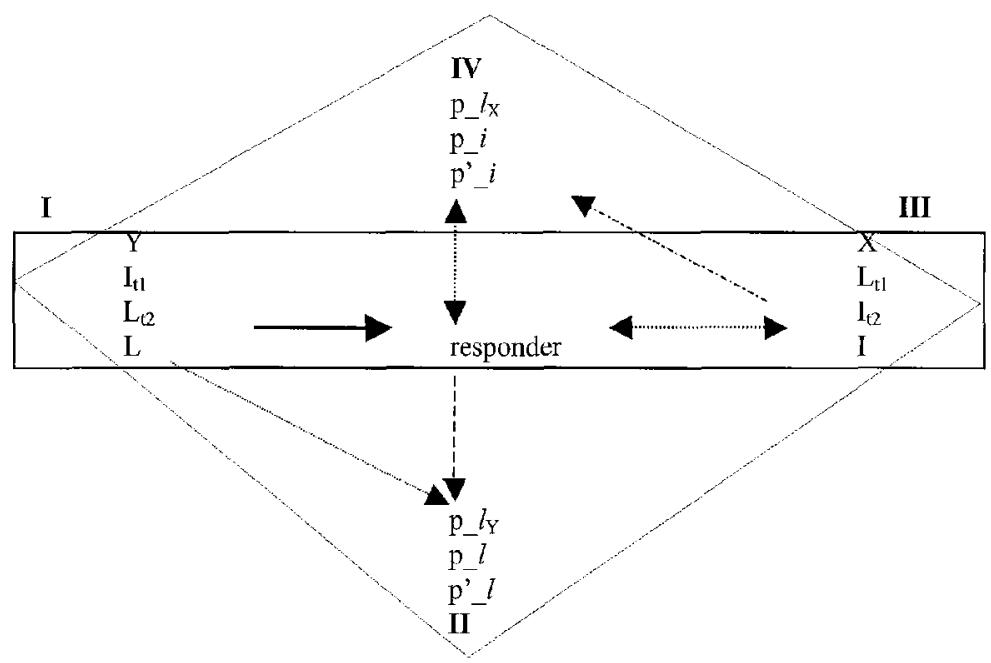

Figura 11. Espacio operativo de responder.

Contestar, en cambio, denota una reacción legitimada en el plano semiótico. Perfila más bien el eje que va del polo II al polo IV: el enunciado cuenta más cumo parte de un guión que como reacción de $Y$, ya que el que «contesta» lo hace en virtud de un papel socio-simbólico que le toca desempeñar en una escena dialogal o un marco institucional. La relación que resalta vienc marcada en la figura 12 por el rectángulo vertical.

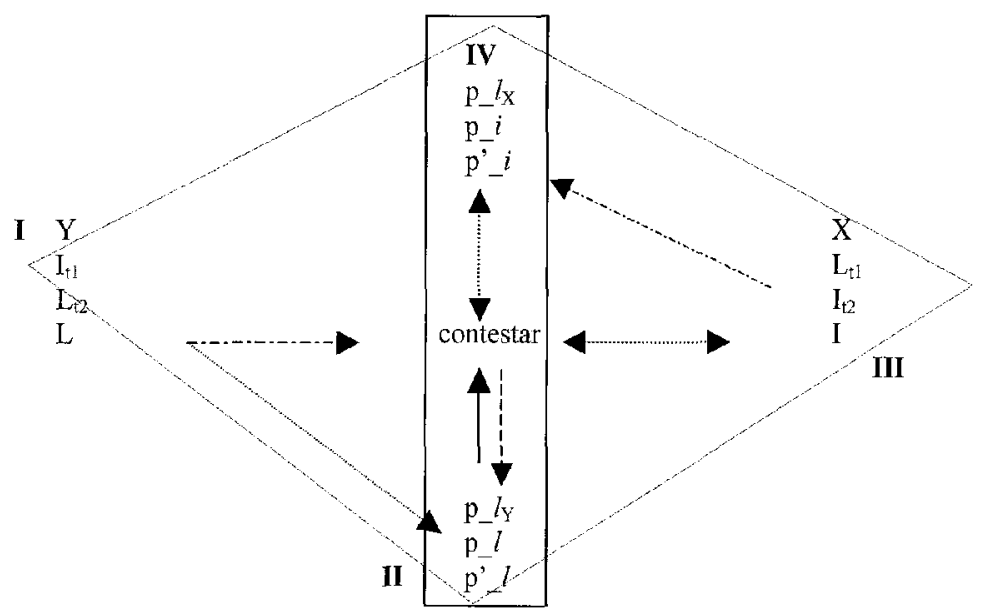

Figura 12. Espacio opcrativo de contestar. 
El que las figuras 11 y 12 sean variantes de la figura 10 muestra que el estudio de la compleja interacción entre significado léxico, potencial construccional y uso discursivo permite llegar a una aclaración integrada e integradora de los predicados de RESPUESTA.

\section{REFERENCIAS BIBLIOGRÁFICAS}

Bourdieu, Pierre (1982): Ce que parler veut dire. L'économie des échanges linguistiques. París, Fayard.

Brown, P. \& S.C. Levinson (1987): Politeness. Some universals in language usage. Cambridge, Cambridge University Press.

Delbecque, Nicole \& Béatrice Lamiroy (1996): «Towards a typology of the Spanish dative». En Van Belle W. \& W. Van Langendonck (cds) The Dative. Descriptive Studies. Ámsterdam, J. Benjamins, págs. $73-117$.

Delbecque, Nicole (1996): «Towards a Cognitive Account of the Use of the Prepositions por and para in Spanishs. En Casad, E. (ed.) Cognitive Lingristics in the Redwoods, The Expansion of a New Paradigm in Linguistics. Nueva York / Berlín, Mouton De Gruyter, págs. 249-318.

Delbecque, Nicole (2000): «Cognitive constraints on complement clause cliticization in Spanish». En Horie, K (ed.) Complementation. Cognitive and Functional Perspectives. Amsterdam, John Benjamins, págs. 149-196.

Delbecque, Nicole (2002): «A construction grammar approach to transitivity in Spanish». En Davidse, K. \& B. Lamiroy (eds) The Nominative/Accusative. Case and Grammatical Relations across Language Boundaries. Amsterdam, J, Benjamins, págs. 273-322.

Delbecque, Nicole (2003): «La variable expresión del agente en las construcciones pasivas», Nueva Revista de Filología Hispánica LI, 2, págs. 373-416.

Delbecque, Nicole (2004): "Spanish ya: a Mental Space Account). En Soares da Silva, A., A.Torres, M. Gonçalves (eds.) Linguagem, Cultura e Cognição: Estudos de Linguistica Cognitiva. Coimbra, Almedina 2004, págs. 363-390.

Goldberg, Adele E. (1995): A Construction Grammar Approach to Argument Structure. Chicago / Londres, University of Chicago Press.

Goffman, Erving (1959): The Presentation of Self in Everyday Life. Nueva York, Anchor Books.

Goffman, Erving (1967): Interactional Ritial. Nueva York, Anchor Books.

Goffman, Erving (1974): Frame Analysis. An essay on the onganization of experience. Nueva York, Harper \& Row.

Grice, H.P. (1975): «Logic and conversation». En Cole, P. \& J.L. Morgan (eds) Syntax and Semantics, vol.3: Speech acts. Nueva York, Academic Press, págs. 41-59.

Lakoff, George (1987): Women, Fire, and Dangerous Things: What Categories Reveal about the Mind. Chicago, University of Chicago Press.

Lakoff, George (1990): «The Invariance Hipótesis: Is Abstract Rcason Based on Image-Schemas?», Cognitive Linguistics 1, págs. 39-74.

Langacker; Ronald W. (1991): Foundations of Cognitive Grammar. Vol. 2: Descriplive Application. Stanford, Cal., Stanford University Press.

Levin, Beth (1993): English Verb Classes and Alternations. Chicago, University of Chicago Press.

Newman, John (1996): Give. A Cognitive Linguistic Study, Berlín /Nueva York, Mouton de Gruyter.

Reddy, Michael J. (1979): "The Conduit Metaphor - A Case of Frame Conflict in Our Language about Language». En Ortony, A. (ed.) Metaphor and Thought. Cambridge, Cambridge University Press.

Trujillo, Ramón (1988): Introducción a la semántica española. Madrid, Arco / Libros.

Turner, Mark (1990): «Aspects of the Invariance Hypothesis», Cognitive Linguisficss 1, págs. 247255. 
Turner, Mark (1993): « $\Lambda$ n Image-Schcmatic Constraint on Metaphor». En Geiger, R. A. \& B. RudzkaOstyn (eds) Conceptualizaiions and Mental Processing in Language. Berlín /Nueva York, Mouton de Gruyter, págs. 291-306.

Wierzbicka, Anna (1980): Lingua Mentalis. The Semantics of Natural Language. Sydney, Academic Press.

Wierzbicka, Anna (1987): English Speech Act Verbs. Sydney, Academic Press. 